\title{
Phytoplankton dynamics in the southern New Caledonian lagoon during a southeast trade winds event
}

\author{
Jacques Neveux ${ }^{\mathrm{a}, \mathrm{b}, *}$, Jean-Pierre Lefebvre ${ }^{\mathrm{c}}$, Romain Le Gendre ${ }^{\mathrm{c}, \mathrm{d}}$, Cécile Dupouy ${ }^{\mathrm{c}}$, Francis Gallois ${ }^{\mathrm{e}}$, \\ Claude Courties $^{\mathrm{f}, \mathrm{g}}$, Philippe Gérard ${ }^{\mathrm{c}}$, Jean-Michel Fernandez ${ }^{\mathrm{c}}$, Sylvain Ouillon ${ }^{\mathrm{h}}$ \\ ${ }^{a}$ UPMC-Université Paris6, UMR 7621, Observatoire Océanologique de Banyuls, F-66651 Banyuls sur Mer, France \\ b CNRS, UMR7621, Laboratoire d'Océanographie Biologique de Banyuls, Avenue Fontaulé, F-66651 Banyuls sur Mer, France \\ ' Institut de Recherche pour le Développement, UR Camélia (UR 103), BP A5, 98848 Nouméa Cedex, New Caledonia \\ d Laboratoire Environnement Ressources de Normandie, Station IFREMER, Avenue du Général de Gaulle, BP 32, 14520 Port en Bessin, France \\ e Institut de Recherche pour le Développement, US191, BP A5, 98848 Nouméa Cedex, New Caledonia \\ ${ }^{\mathrm{f}}$ CNRS, UMS 2348, Observatoire Océanologique, F-66651, Banyuls sur Mer, France \\ g UPMC-Université Paris6, UMS 2348, Observatoire Océanologique, F-66651, Banyuls sur Mer, France \\ ${ }^{\text {h }}$ Université de Toulouse; IRD; UPS (OMP-PCA); LEGOS; 14 Avenue Edouard Belin, F-31400 Toulouse, France
}

\section{A R T I C L E I N F O}

\section{Article history:}

Received 9 February 2010

Received in revised form 21 May 2010

Accepted 21 May 2010

Available online 2 June 2010

\section{Keywords:}

Chlorophyll

Phycoerythrin

Flow cytometry

Phytoplankton

In vivo fluorescence

Growth rate

Trade winds

Lagoon

Internal wave

New Caledonia

\begin{abstract}
A B S T R A C T
During the Echolag cruise (13 February-8 March 2007), the effect of 16-30 knot trade winds on abundance, community structure and dynamics of phytoplankton was investigated in the southern part of the New Caledonian coral reefs and surrounding oceanic waters. In this area, the coral reefs form two horn-like structures (hereinafter referred to as 'horn reefs'), oriented south-east, and separated by a relatively deep valley. Three repeated samplings at one week intervals of a 32 station array showed that trade winds induce surface water cooling and significant enrichment of mid- and bottom waters above the reef shelf. This enrichment appeared as the result of a general rise of the oceanic thermocline and nitracline due to the combination of trade winds and tidally-generated internal waves between the horn reefs. It was accompanied by a factor of 1.5 and 2.3 mean increase for the chlorophyll concentration and picoplankton-nanoplankton cell number, respectively. From diel variations of in vivo chlorophyll $a$ fluorescence and hourly sampling, phytoplankton gross growth rate was estimated to be 1-1.35 divisions per day and was quasi balanced with phytoplankton mortality for a $24 \mathrm{~h}$ period.
\end{abstract}

(c) 2010 Elsevier B.V. All rights reserved.

\section{Introduction}

The New Caledonia archipelago, located in the southwest Pacific Ocean (Coral Sea), is surrounded by a large lagoon system covering an area of $22,175 \mathrm{~km}^{2}$ (Andréfouët et al., 2009). The major part of the lagoon enclosing the main island (Grande Terre), receives river outflows and run-off from the steep slopes bordering the lagoon that stimulate phytoplankton growth and productivity in the lagoon

\footnotetext{
Abbreviations: SWL, Southwest lagoon; THL, two horn lagoon; RALS, light scatter at right angle; PE, phycoerythrin; PEB, phycoerythrobilin; PUB, phycourobilin; IVF, in vivo chlorophyll $a$ fluorescence.

* Corresponding author. UPMC-Université Paris6, UMR 7621, Observatoire Océanologique de Banyuls, F-66651 Banyuls sur Mer, France.

E-mail addresses: jneveux@obs-banyuls.fr, jcqsnv@aol.com (J. Neveux), j-p.lefebvre@orange.fr (J.-P. Lefebvre), romain.le.gendre@ifremer.fr (R. Le Gendre), Cecile.Dupouy@noumea.ird.nc (C. Dupouy), Francis.Gallois@noumea.ird.nc (F. Gallois), claude.courties@obs-banyuls.fr (C. Courties), Philippe.gerard@noumea.ird.nc (P. Gérard), jean-michel.fernandez@noumea.ird.nc (J.-M. Fernandez), sylvain.ouillon@ird.fr (S. Ouillon).
}

(Tenório et al., 2005; Jacquet et al., 2006). Development of mining activities (nickel and chrome) also increases land erosion during runoff (Ouillon et al., in press) that may impact the lagoon ecosystem. Historically, main environmental studies have been conducted in the southwest part of the lagoon ( $\mathrm{SWL}$ ) from the Ouen Island-Mato pass axis to Saint-Vincent Bay (Fig. 1). In the SWL, urban activities related to the extension of the capital Nouméa are continuously increasing and could affect local productivity of the lagoon by eutrophication (Fichez et al., in press). Through exchanges with the lagoon, the ocean is generally considered as an oligotrophic vector for it. In the SWL, ocean-lagoon exchanges are limited to narrow passes in the barrier reef, but input of oceanic waters also occurs by waves breaking over the barrier reef (Bonneton et al., 2007). Although other parts of the lagoon which were occasionally sampled deserve to be investigated further, two main reasons justified focussing on the water circulation and phytoplankton dynamics at the southeast of Grande Terre where the reefs form a two horn-like structure (hereinafter referred to as 'horn reefs') and the lagoon is more open to the ocean (see Fig. 1). 


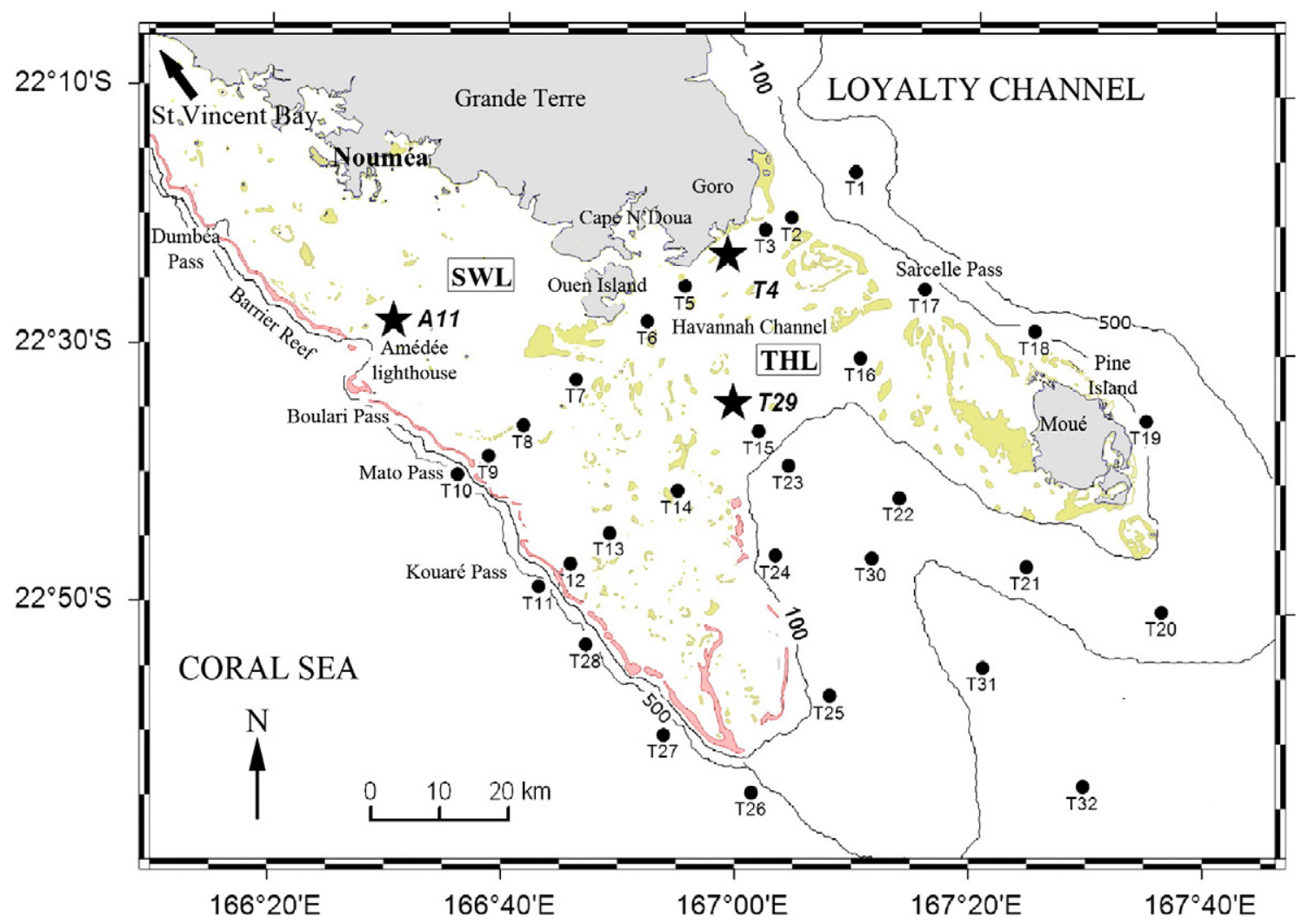

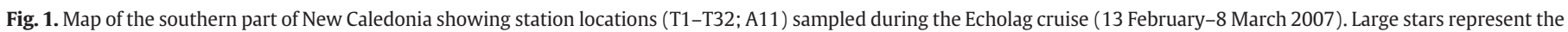
25 h time series stations.

First, the commissioning of a new nickel extraction plant at Goro (Fig. 1) that will discharge its effluent in the Havannah Channel, which may modify the productivity of the lagoon. And second, when trade winds are blowing, satellite and in situ observations show water cooling along the SWL barrier reef and between the two horn reefs because of upwelling (Hénin and Cresswell, 2005; Neveux et al., 2009; Ganachaud et al., in press). Temperature decreases of up to $5{ }^{\circ} \mathrm{C}$ can occur in summer, however it is not clear if this phenomenon is systematically associated with a significant nutrient enrichment of surface waters and increases of phytoplankton biomass ( $\operatorname{chl} a$ ) as well as modification of phytoplankton community structure and dynamics.

The Echolag project was created to determine the general circulation and the ocean-lagoon exchanges in the lagoon area delimited by the two horn reefs (THL). A second objective was to determine if trade winds and the circulation between the two horns can enrich the ocean near the reef in summer and modify the phytoplankton community structure before and after entering the lagoon. The variations in the community structure also add useful information for a comprehensive view of the circulation in the THL zone. The third objective was to quantify phytoplankton dynamics in the lagoon using the in situ daynight variations of in vivo fluorescence at three fixed stations. Spatial heterogeneity at small scales and water movements are often unfavourable for observing in situ diel variations of phytoplankton abundance. However, the in situ diel signal could be captured at the scale of large water masses, like was done in the upwelling waters of the equatorial Pacific Ocean (Dandonneau and Neveux, 1998; Claustre et al., 1999; Neveux et al., 2003). The present paper deals mainly with the second and third objectives of the Echolag project: the trade wind effect on enrichment and phytoplankton community in the THL zone, and the quantification of phytoplankton dynamics through analysis of the in situ diel signals at two locations in the THL and comparison with one station in the SWL.

\section{Materials and methods}

\subsection{Sampling}

Sampling was done during the Echolag cruise on the R/V Alis (13 February-8 March 2007). Two types of surveys were completed: 1) an array of 32 short-duration (30-60 min) stations (T1 to T32) that were sampled at approximately one week intervals during each of the three legs (Fig. 1); 2) $25 \mathrm{~h}$ time series at three fixed mooring stations (T4, T29 in the THL and A11 in the SWL). At all stations, vertical profiles of temperature (two sensors), conductivity (two sensors), density $\left(\sigma_{\theta}\right)$ and pressure were measured with a CTD SEABIRD SBE 19 fixed on a stainless steel structure. This structure was also equipped with a rosette of 8-L Niskin bottles for water sampling and with a WETStar fluorometer (WETLabs) adapted for in vivo chlorophyll $a$ fluorescence measurements. At each short-duration station, water was taken at 3 depths (lagoon stations) or 6 depths (oceanic stations). For the $25 \mathrm{~h}$ stations, water samplings were done approximately each hour at three depths and ammonium assessment and phytoplankton cell counts by flow cytometry were performed at low and high tides (approximately every $6 \mathrm{~h}$ ). The first Leg (14-16 February) and second Leg (24-26 February) sampling campaigns lasted 58 and $54 \mathrm{~h}$ respectively. However, bad swell conditions during the third period (Leg3: 3-4 March) led to cancelling the planned sampling at most of the oceanic stations.

The sampling array was composed of three main transects, two across the horn reefs (T1-T10 and T11-T17), and one in the axis of the valley between the horn reefs (T6-T32); these sites were completed by a series of oceanic stations all around the THL (T17-T22; T24-T28). In order to compare pigment distribution and community structure changes during trade winds events, it was convenient to divide the stations into two categories: the lagoon stations (bottom $\leq 80 \mathrm{~m}$, 
$n=14$ : T2-T9; T12-T16; T29) which included stations located on the reef shelf (but not within the lagoon) and oceanic stations ( $n=18$ : T1; T10-T11; T17-T28; T30-T32).

Horizontal currents were measured with ADCP current meters (Workhorse sentinel $300 \mathrm{kHz}, \mathrm{RDI}$ ) moored at the bottom of stations $\mathrm{T} 4$ and T16bis $\left(22^{\circ} 27^{\prime} \mathrm{S}-167^{\circ} 14^{\prime} \mathrm{E}\right.$; between T16 and T17) during the entire cruise.

\subsection{Nutrient analyses}

For nitrate, phosphate and silicate determinations, triplicate water samples (20 mL each) were poisoned with $\mathrm{HgCl}_{2}$ (Kattner, 1999) and maintained at $4{ }^{\circ} \mathrm{C}$ before analysis at the local laboratory of the Institut de Recherche pour le Développement (IRD-Nouméa). Nitrates were reduced to nitrites (Wood et al., 1967) and the summed $\mathrm{NO}_{3}+\mathrm{NO}_{2}$ $\left(\mathrm{NO}_{3}+2\right)$ determined by the method described in Raimbault et al. (1990) (detection limit $=0.002 \mu \mathrm{M}$; accuracy $= \pm 0.002 \mu \mathrm{M}$ ). Soluble reactive phosphorus $\left(\mathrm{PO}_{4}\right)$ was measured according to Grasshoff et al. (1983) (detection limit $=0.01 \mu \mathrm{M}$; accuracy $= \pm 0.05 \mu \mathrm{M}$ ) and silicates according to the silico-molybdic acid method developed by Mullin and Riley (1955), as modified by Fanning and Pilson (1973) (detection limit $=0.05 \mu \mathrm{M}$; accuracy $= \pm 0.05 \mu \mathrm{M}$ ). All assays were performed on a Bran + Luebbe autoanalyzer III.

Ammonium concentration was assayed (3 replicates of unfiltered $40 \mathrm{~mL}$ samples) during the cruise by fluorometry using the ophthaldialdehyde method (Holmes et al., 1999). Fluorescence was measured on a Turner TD-700, 6-12 h after the reagent addition (detection limit $=0.002 \mu \mathrm{M}$; accuracy $= \pm 0.010 \mu \mathrm{M}$ ).

\subsection{Chlorophylls and phaeopigments determination}

The $0.53 \mathrm{~L}$ water samples were filtered on $25 \mathrm{~mm}$ GF/F filters. The filters were folded, placed into a $1.2 \mathrm{~mL}$ Nunc cryotube and stored in liquid nitrogen. One to two months after sampling, filters were ground in $4 \mathrm{~mL}$ of $95 \%$ acetone (final volume $4.2 \mathrm{~mL}$; final concentration $\approx 90 \%$ acetone taking into account water retention by the filter, i.e., $0.2 \pm 0.012 \mathrm{~mL}$ ) with the freshly broken end of a glass rod for chlorophyll and phaeopigment extraction. Pigments were analysed by spectrofluorometry according to the method described in Neveux and Lantoine (1993), and using recent significant improvements in qualitative and quantitative analysis (Neveux et al., 2003; Tenório et al., 2005). Calculations of pigment concentrations were done from a $31 \times 26$ excitation-emission matrix (806 fluorescence values) by nonnegative linear least squares approximation (Tenório et al., 2005). Concentrations for chlorophyll $a(\operatorname{chl} a), b(\operatorname{chl} b), c\left[\operatorname{chl}\left(c_{1}+c_{2}\right)\right], c_{3}$ $\left(\operatorname{chl} c_{3}\right)$, divinyl-chlorophyll $a(\operatorname{dv}-c h l a)$ and $b(\mathrm{dv}-\mathrm{chl} b)$ were determined by accounting for the possible presence in the extract of phaeopigment derived from each chlorophyll. Fluorescence was measured with a HITACHI F4500 spectrofluorometer.

\subsection{Phycoerythrin estimation}

Filtration of $1 \mathrm{~L}$ water samples was done onto $0.4 \mu \mathrm{m}$ polycarbonate membranes (NUCLEPORE $47 \mathrm{~mm}$ diameter). Filters were folded, put into $1.2 \mathrm{~mL}$ Nunc cryotubes and stored in liquid nitrogen. One to two months after sampling, filters were unfolded with pliers and dipped into a tube containing $4 \mathrm{~mL}$ glycerol-phosphate buffer $(0.1 \mathrm{M}$ $\left.\mathrm{NaH}_{2} \mathrm{PO}_{4}, \mathrm{pH}=6.5\right)$ mixture $(50 / 50: \mathrm{v} / \mathrm{v})$. The tubes were handshaken vigorously and then vortexed for cell re-suspension according to the in vivo Wyman's method (1992). Fluorescence excitation spectra of phycoerythrin were recorded between 450 and $580 \mathrm{~nm}$ (emission at $605 \mathrm{~nm}$ ) on the HITACHI F4500 spectrofluorometer with slit widths of 5 and $10 \mathrm{~nm}$ at the excitation and emission sides respectively. Concentrations of phycoerythrin (PE) were assessed from the area below the fluorescence excitation curves using the calibration procedure described in Lantoine and Neveux (1997). The shape and the peak ratio phycourobilin/phycoerythrobilin (PUB/PEB) of the fluorescence excitation spectra also provided qualitative information about the main cyanobacteria in the communities (Neveux et al., 2006).

\subsection{Cell counts by flow cytometry}

$1 \mathrm{~mL}$ samples were collected in $1.2 \mathrm{~mL}$ Nunc cryotubes for flow cytometric analysis of picoplankton and nanoplankton. They were preserved by a $20 \mu \mathrm{L}$ addition of $10 \%$ paraformaldehyde solution (final concentration: 0.2\%, Campbell and Vaulot, 1993) and then frozen in liquid nitrogen. Thawed samples were analysed between two and three months after sampling at the Observatoire Océanologique de Banyuls (Banyuls sur mer, France) with a FACSCan flow cytometer (BD-Biosciences). For each cell population, light scatter at right angle (RALS), orange and red fluorescence properties and counts were determined. Data were normalized using fluorescent $1.002 \mu \mathrm{m}$ beads (Polysciences Inc., Europe).

2.6. Phytoplankton growth and grazing estimates from in vivo chlorophyll fluorescence and extracted pigment concentration

Estimations of phytoplankton growth and grazing (or more generally phytoplankton mortality) rates from in vivo chlorophyll fluorescence (IVF) variations were made during the $25 \mathrm{~h}$ time series stations. IVF was defined either by the intensity of the fluorescence maximum (Fmax) or by the fluorescence integrated on the water column (Fint). In this case, the upper layer $(0-15 \mathrm{~m})$, where the fluorescence could not be considered as a reliable proxy of chl $a$ concentration on a diel basis, was omitted from the calculation (see Results section). For each fixed station it was possible to observe: 1) a decreasing period (D) from around 15:00-19:00 h to early in the next morning; 2) an increasing period (I) from 06:00-08:00 h to 15:0019:00 h. For each period, exponential regressions from data points were obtained:

$I V F=a \exp (b t)$

where $t$ represents the time in hours and $a$ and $b$ are constants. Assuming that IVF changes during the $\mathrm{D}$ (dark) periods were only due to grazing, the estimated rates of change $(b)$ could therefore be considered as hourly estimates of grazing-associated losses $\left(g\right.$, in $\left.\mathrm{h}^{-1}\right)$. Similarly, the exponential rates of change $(b)$ for the I regressions represent hourly estimates of the difference between specific growth $\left(\mu_{0}\right)$ and grazing rates $\left(\mu_{\mathrm{o}}-g\right.$, in $\left.\mathrm{h}^{-1}\right)$. Specific growth rates were subsequently computed from the differences in daily D and I regressions, assuming that grazing rates were similar in the light and dark. Hourly rates were expressed on a daily basis assuming that grazing occurred over $24 \mathrm{~h}$ while growth was restricted to the light (I) periods.

\subsection{Meteorological information}

Rainfall and wind speed and direction were obtained from Météo France at three stations: 1) Amédée Island station (near A11) located near the Boulari Pass, 2) Cape Ndoua and 3) Moué (Pine Island station). At Moué station, global solar irradiation was also measured.

\section{Results}

\subsection{Climatic conditions}

The week-long period preceding the cruise was characterized by moderate winds with fluctuating direction. The cruise started during west-southwest wind conditions (11-14 February: 10-15 knots), then winds turned rapidly to east-southeast (trade winds) with speed 
increasing all along the cruise period (16-30 knots: Fig. 2A, B), consequently, the first sampling (Leg1) occurred before the establishment of a constant trade winds regime. Rainfall was in the range of normal climate conditions for summer in New Caledonia $(60-90 \mathrm{~mm}$ cumulative rain during the 20 days of water sampling: Fig. 2C). The first and second (Leg2) sampling legs were conducted under clear weather conditions (global solar radiation: 1938 and $1846 \mathrm{~J} \mathrm{~cm}^{-2} \mathrm{~d}^{-1}$, respectively) whereas important cloud cover $\left(663 \mathrm{~J} \mathrm{~cm}^{-2} \mathrm{~d}^{-1}\right.$ : Fig. 2D) prevailed during the third leg (Leg3).

\subsection{Physical parameters}

During Leg1, surface water temperature ranged from 25.48 to $27.11^{\circ} \mathrm{C}$ (Table 1). The coldest waters entered the lagoon by the north (T1 and T2) and showed a minimum at T16, in the Sarcelles Pass $\left(25.48{ }^{\circ} \mathrm{C}\right)$. After ten days of trade winds, the average (all stations; $n=32$ ) surface temperature decreased by $0.8^{\circ} \mathrm{C}$. A positive SW-NE temperature gradient appeared across the horn reefs with values lower than $25.30{ }^{\circ} \mathrm{C}$ at the south and south west (minima $24.82-24.86^{\circ} \mathrm{C}$ at $\mathrm{T} 10, \mathrm{~T} 11$ and T32) and higher than $27.10^{\circ} \mathrm{C}$ in the Loyalty Channel (maxima at T1, T17 and T18: 27.24- $\left.27.26{ }^{\circ} \mathrm{C}\right)$. The maximum decrease was observed at T11 $\left(-2.25^{\circ} \mathrm{C}\right)$ and the maximum increase at $\mathrm{T} 2\left(+1.37^{\circ} \mathrm{C}\right)$. During Leg3, waters tended to be slightly warmer, except between the horn reefs where an additional $0.4{ }^{\circ} \mathrm{C}$ decrease occurred. A more important temperature decrease was noted between Leg1 and Leg2 near the bottom of some lagoon stations as for example at T15 $\left(-3.66{ }^{\circ} \mathrm{C}\right), \mathrm{T} 13\left(-3.08^{\circ} \mathrm{C}\right)$, and $\mathrm{T} 6\left(-2.70{ }^{\circ} \mathrm{C}\right)$. In the longitudinal axis of the bay between the horn reefs (T6-T32), the isotherms above $22^{\circ} \mathrm{C}$ were closer to the surface during Leg2 than during Leg1, but the isotherm $21.5^{\circ} \mathrm{C}$ was at a similar level (110-130 m: Fig. 3). However, at $150 \mathrm{~m}$, the coldest temperature $\left(19.62{ }^{\circ} \mathrm{C}\right)$ recorded at T23 (Leg1 near the bottom) was comparable to temperatures at $200 \mathrm{~m}$ depth in surrounding oceanic waters (T1, T17-T18 and T10-T11).

During Leg1, the surface salinity was maximal at T3-T6 (35.5535.60) and decreased in all sampling directions with the minimum at T21 (35.16). During Leg2, there was a positive NE-SW gradient (35.10-35.15 in the Loyalty Channel; 35.50-35.55 along the barrier reef at the southwest: T10-T26 transect). No linear correlation between surface temperature and salinity $\left(R^{2}=0.01 ; n=32\right)$ was found during Leg1; they were negatively correlated during Leg2 $\left(R^{2}=0.93 ; n=32\right)$ and Leg3 $\left(R^{2}=0.88 ; n=21\right)$.

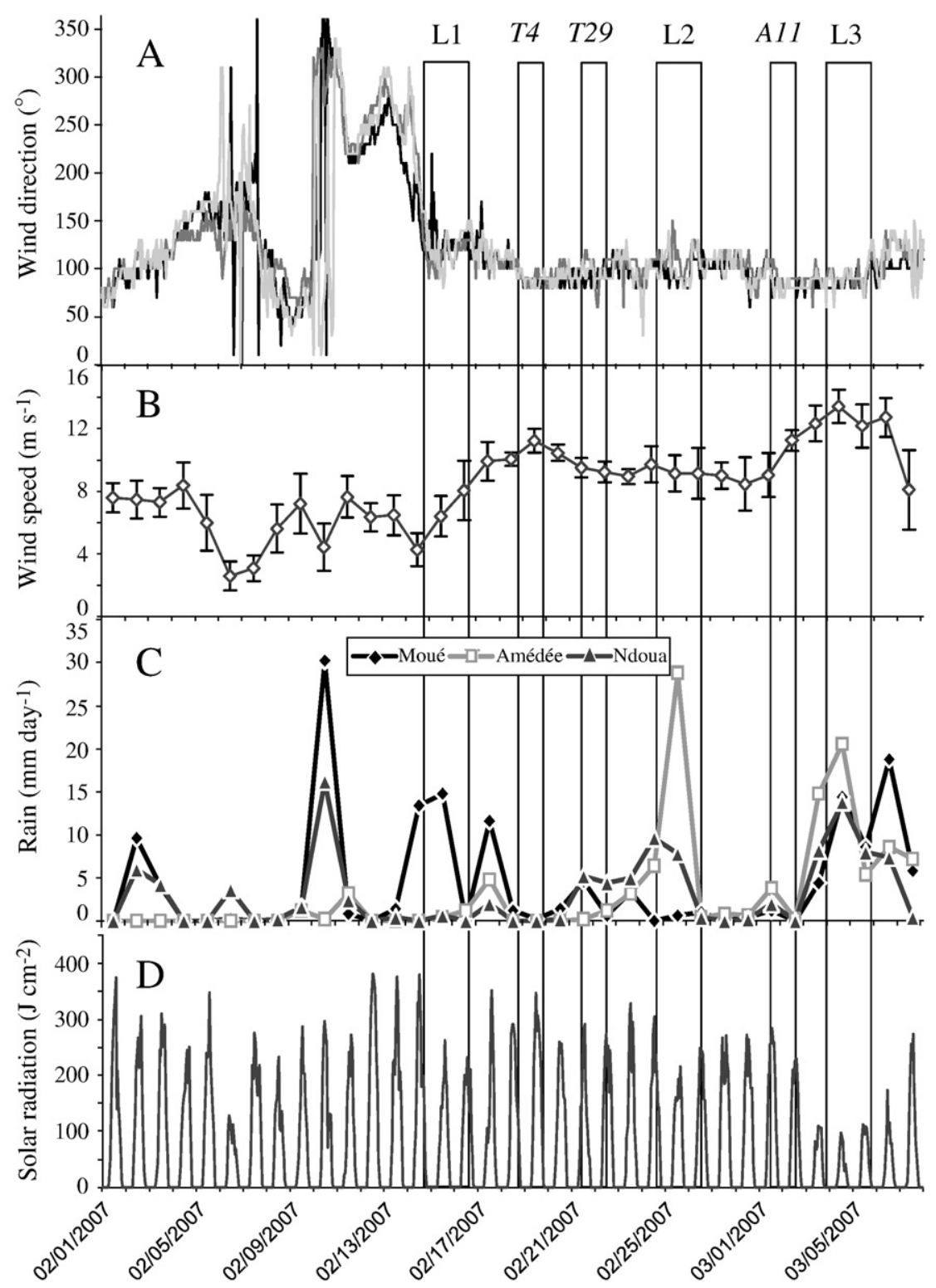

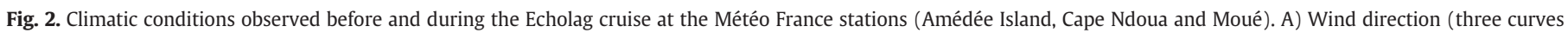
overlayed), B) wind speed (mean and standard deviation), C) precipitation, D) solar irradiation (Moué station only). 
Table 1

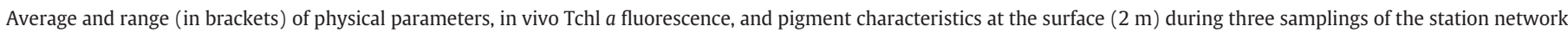
(Leg1 = 14-16 February 2007; Leg2 = 24-26 February 2007, Leg3=3-4 March 2007); w = weight.

\begin{tabular}{|c|c|c|c|c|}
\hline Parameter & Units & Leg1 $(n=32)$ & Leg2 $(n=32)$ & Leg3 $(n=21)$ \\
\hline Temperature & ${ }^{\circ} \mathrm{C}$ & $26.57(25.48-27.11)$ & $25.81(24.80-27.26)$ & 25.78 (24.95-26.95) \\
\hline Salinity & & $35.39(35.16-35.60)$ & $35.34(35.10-35.53)$ & $35.34(35.16-35.54)$ \\
\hline Density $\left(\sigma_{\theta}\right)$ & & $23.17(22.93-23.91)$ & $23.35(22.73-23.80)$ & $23.35(22.87-23.73)$ \\
\hline Fluorescence & (r.u.) & $0.489(0.233-1.205)$ & $0.718(0.262-1.84)$ & $1.30(0.36-3.08)$ \\
\hline Tchl $a$ & $\mu g \mathrm{~L}^{-1}$ & $0.217(0.089-0.481)$ & $0.29(0.114-0.689)$ & $0.397(0.208-0.733)$ \\
\hline Chl $a$ & $\mu \mathrm{g} \mathrm{L}^{-1}$ & $0.169(0.050-0.458)$ & $0.238(0.070-0.601)$ & $0.337(0.151-0.670)$ \\
\hline Chl $b / C h l a$ & $\%(w / w)$ & $12(8-17)$ & $13(6-25)$ & $18(7-29)$ \\
\hline Chl $c_{1+2} /$ Chl $a$ & $\%(w / w)$ & $10(7-15)$ & $10(6-19)$ & $10(8-16)$ \\
\hline Dv-chl $a /$ Tchl $a$ & $\%(w / w)$ & $29(4-55)$ & $20(4-55)$ & $16(7-37)$ \\
\hline $\mathrm{PE}$ & $\mu \mathrm{g} \mathrm{L}^{-1}$ & $0.48(0.07-2.05)$ & $0.49(0.06-1.35)$ & $0.83(0.17-1.74)$ \\
\hline PUB/PEB & & $1.14(0.64-1.84)$ & $1.30(0.79-1.64)$ & $1.57(1.11-1.77)$ \\
\hline
\end{tabular}

\subsection{Nutrients}

At the surface $(2 \mathrm{~m}), \mathrm{NO}_{3+2}$ concentrations were generally low during Leg1 (maximum value of $0.12 \mu \mathrm{M}$ at T24). Leg2 showed a slight mean $\mathrm{NO}_{3+2}$ increase (Table 2 ) and concentrations exceeded $0.12 \mu \mathrm{M}$ at three stations (maximum $0.18 \mu \mathrm{M}$ at T4). The highest concentrations were observed during Leg3 with values between 0.25 and $0.35 \mu \mathrm{M}$ at T3, T5, T9, T16 and T21. Considering the entire water column at the lagoon stations and the $0-80 \mathrm{~m}$ layer in the surrounding ocean, concentrations of $\mathrm{NO}_{3+2}$ never exceeded $1 \mu \mathrm{M}$ during Leg1 with a maximum value at T19 (80 m: $0.85 \mu \mathrm{M})$. Relatively high concentrations were also measured in the lagoon stations that were the closest to the ocean (T29 at $75 \mathrm{~m}: 0.67 \mu \mathrm{M}$ ). During Leg2, a significant increase occurred near the bottom of some parts of the lagoon (T2-T6 and T14-T16) with a maximum of $1.58 \mu \mathrm{M}$ at T6 (Fig. 4). Furthermore, several oceanic stations also showed concentrations $>1.5 \mu \mathrm{M}$ from $60 \mathrm{~m}$ (T22), $70 \mathrm{~m}$ (T30) or $80 \mathrm{~m}$ (T1, T19 and T24). During Leg3, the concentrations tended to be lower than during Leg2 in the lagoon, when they were still high at T15-T16 $(>1 \mu \mathrm{M}$ near the bottom). In the ocean, concentrations $>1 \mu \mathrm{M}$ were not observed above $80 \mathrm{~m}$, but the heavy swell prevented sampling at 11 stations.

Phosphate also showed a slight mean increase between Leg1 and Leg2 in surface and deep waters (Table 2). During Leg1, the N/P ratio
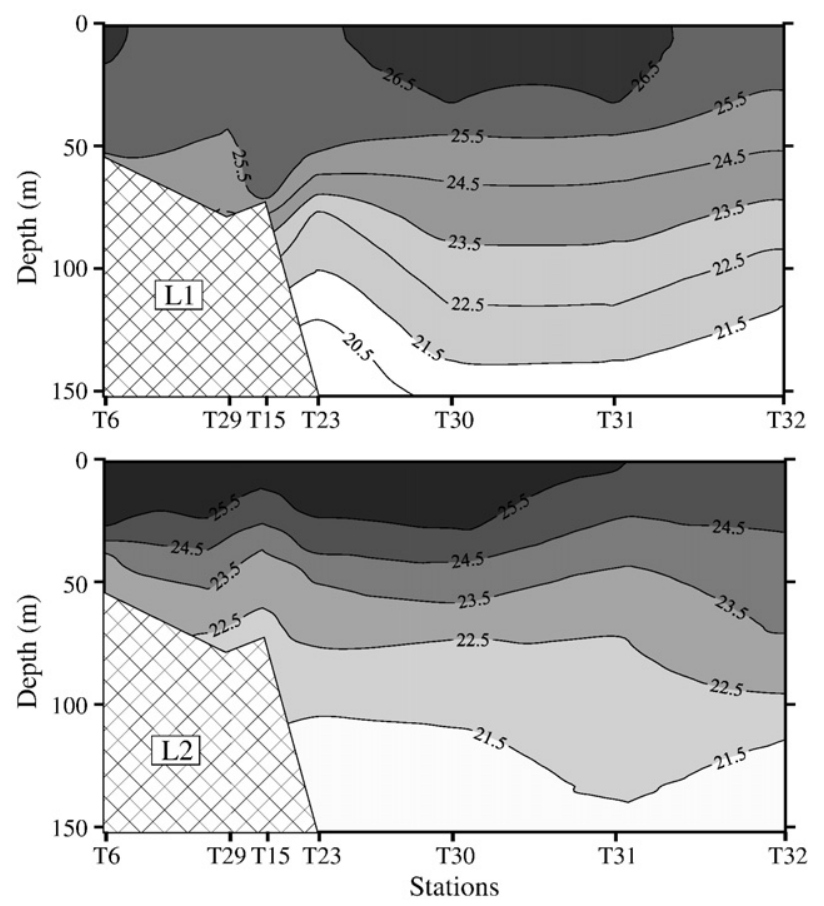

Fig. 3. Depth distribution of temperature $\left({ }^{\circ} \mathrm{C}\right)$ along the transect T6-T32 during A) Leg1 (L1), B) Leg2 (L2). was generally lower $(<8)$ than the Redfield ratio with mean values of 2 and 4 in the lagoon and in the ocean, respectively. The mean ratio increased during Leg2 in deep waters (around 6 in the lagoon and in the $0-80 \mathrm{~m}$ layer of the ocean) and the high values of $\mathrm{NO}_{3}+2$ were associated with N/P ratios near the Redfield ratio (13-18). Added to a significant decrease of temperature, this pattern indicated that intrusion of oceanic deep waters on the continental shelf enriched the reef shelf up to the T6 site (as illustrated by the nitrate sections along the transect T32-T6 during L1 and L2, Fig. 4). Silicate and ammonium concentrations did not show remarkable trends (Table 2).

\subsection{In vivo chl a fluorescence and relationships with extracted chlorophyll concentrations}

When compared to Leg1, a mean 40-50\% increase of in vivo chl a fluorescence (IVF) occurred at the surface of the sampling area during Leg2 (Table 1). The IVF increased again from Leg2 to Leg3 in most parts of the lagoon and mainly between the horn reefs where a threefold increase could be observed (stations T21-T23 and T29) when compared to Leg2 conditions. These general trends characterized the changes in Tchl $a$ abundance and distribution also. The Tchl $a$ concentration and the IVF signal were as well correlated for the entire cruise data set (Tchl $a=0.241$ [IVF] $+0.100 ; R^{2}=0.75 ; n=525$; IVF measured during bottle closure) as for the data subsets corresponding to the three Legs (Table 3). The comparison of the regression lines obtained for Leg1, Leg2 and Leg3 showed a significant decrease of the slopes and an increase of the intercepts. The intercepts suggested that a part of Tchl $a$ was overlooked by the fluorescence signal and their increase could correspond to the increase of cells of relatively large size in low concentrations. This can be explained by the extracted chlorophyll measurement which integrates pigment included in $530 \mathrm{~mL}$, whereas the IVF concerns an average of ten instantaneous measurements of fluorescence on a smaller volume $(0.25 \mathrm{~mL})$. Furthermore, the slope increases indicated an increase of cell populations with a high fluorescence number (high IVF/chl $a$ ratio). The poorest relationships were observed for surface samples during the $25 \mathrm{~h}$ time series which is explained by a reduction in the IVF/Tchl $a$

Table 2

Nutrient concentrations (mean \pm standard deviation) measured during the three samplings of the stations network (Leg1 = 14-16 February 2007; Leg2 $=24-26$ February 2007, Leg3 = 3-4 March 2007). S = surface samples ( $2 \mathrm{~m}$ ); B=samples taken $2 \mathrm{~m}$ above the bottom at lagoon stations and at $80 \mathrm{~m}$ for the remainder.

\begin{tabular}{llclll}
\hline Sampling & $\mathrm{NO}_{3}+\mathrm{NO}_{2}(\mu \mathrm{M})$ & $\mathrm{PO}_{4}(\mu \mathrm{M})$ & $\mathrm{SiO}_{4}(\mu \mathrm{M})$ & $\mathrm{NH}_{4}(\mu \mathrm{M})$ \\
\hline Leg1 & $\mathrm{S}$ & $0.044 \pm 0.035$ & $0.027 \pm 0.015$ & $0.60 \pm 0.22$ & $0.035 \pm 0.026$ \\
$n=32$ & $\mathrm{~B}$ & $0.19 \pm 0.22$ & $0.053 \pm 0.028$ & $0.64 \pm 0.22$ & $0.062 \pm 0.050$ \\
Leg2 & $\mathrm{S}$ & $0.068 \pm 0.068$ & $0.031 \pm 0.012$ & $0.74 \pm 0.19$ & $0.028 \pm 0.021^{\mathrm{a}}$ \\
$n=32$ & $\mathrm{~B}$ & $0.69 \pm 0.78$ & $0.087 \pm 0.036$ & $0.78 \pm 0.19$ & $0.049 \pm 0.033^{\mathrm{a}}$ \\
Leg3 & $\mathrm{S}$ & $0.12 \pm 0.11$ & $0.048 \pm 0.017$ & $0.67 \pm 0.20$ & $0.036 \pm 0.020^{\mathrm{a}}$ \\
$n=21$ & $\mathrm{~B}$ & $0.34 \pm 0.44$ & $0.076 \pm 0.035$ & $0.71 \pm 0.20$ & $0.080 \pm 0.052^{\mathrm{a}}$ \\
\hline
\end{tabular}

a Only lagoon stations for $\mathrm{NH}_{4}$ : T2-T16 and T29 $(n=16)$. 

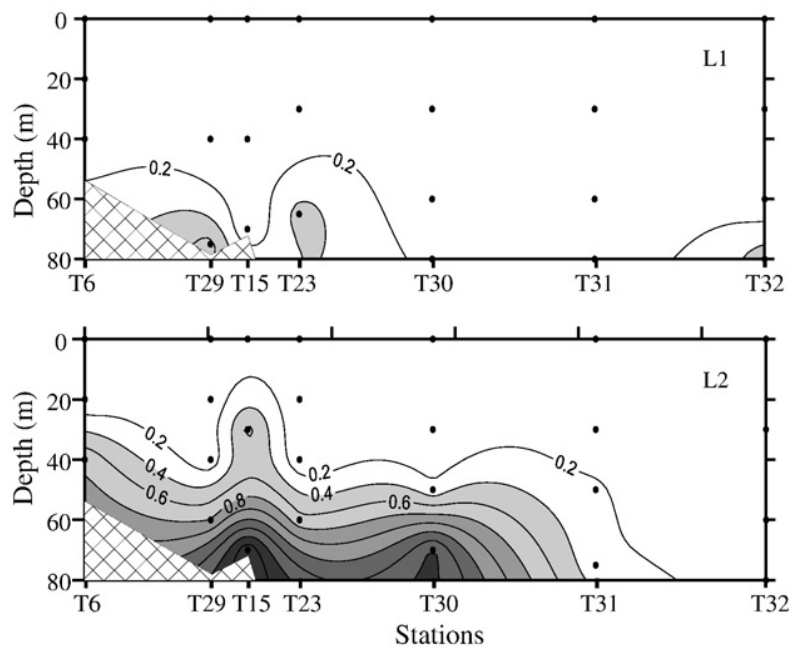

Fig. 4. Depth distribution of nitrates + nitrites $(\mu \mathrm{M})$ along the transect T6-T32 during A) Leg 1 (L1), B) Leg 2 (L2).

ratio due to strong light effects on physiological properties of cells during clear and sunny days (Kiefer, 1973); however, this concerned data spanning a relatively small range. Generally, chl $b$, chl $c_{1}+c_{2}$ or sometimes both appeared more correlated to IVF than Tchl $a$ suggesting that part of the measured fluorescence is associated with photosensitization of chl $a$ via light absorption by accessory pigments (dependent on wavelength range of the excitation light, $455 \pm 5 \mathrm{~nm}$ for the Wetstar fluorometer).

\subsection{Chlorophylls and phycoerythrins}

Monitoring the changes in concentration of chlorophyll and phycoerythrin as well as pigment ratios helped to assess the effect of trade winds on the phytoplankton composition of surface waters (Tables 1 and 4). Tchl a concentration represents the sum of two components: the chl $a$ from eukaryotes and cyanobacteria (except Prochlorococcus) and dv-chl $a$, specific to Prochlorococcus spp. During Leg1, the dv-chl $a$ percentage [dv-chl $\left.a^{*} 100 /(\operatorname{chl} a+\mathrm{dv}-\mathrm{chl} a)\right]$ was higher than $32 \%$ at the oceanic stations. This percentage decreased below 12\% along the lagoon ward T2-T9 transect. Low dv-chl $a$ percentage $(<20 \%)$ was measured in the waters between the reef horns during Leg2 and it increased in the Havannah Channel at stations T2-T4. Globally, the percentage tended to decrease during the study. The average chl $b /$ chl $a$ ratio $(b / a)$ measured during Leg1 was similar in the lagoon and the ocean (0.12) with a $b / a$ maximum of 0.17 at T16 (Sarcelle Pass). This mean ratio increased all along the study in the lagoon (Leg2: 0.16; Leg3: 0.18). The highest $b / a$ values were observed at T3-T6 (0.25-0.3 during Leg3). In the oceanic sites, the mean $b / a$ ratio was slightly lower during Leg2 than during Leg1. During Leg3, the ratio increased between the horns (T21-T23: 018-0.2). At the T12-T14

\section{Table 3}

Linear regressions between extracted total chlorophyll $a$ and in vivo chl $a$ fluorescence [Tchl $a=f(\mathrm{IVF})]$, for all samples of the Echolag cruise and data subsets corresponding to different operations and depth. Unc. = Uncorrelated; $\mathrm{p}$ was omitted when $<0.001 . R^{2}=$ determination coefficient; RIVF and RTchl $a=$ maximum/minimum of in vivo Tchl $a$ fluorescence and extracted Tchl $a$ observed in the data set, respectively; $n=$ sample number. L1 to L3 = Leg 1 to Leg 3.

\begin{tabular}{llllc}
\hline Samples & Slope & Intercept & $R^{2}$ & $n$ (RIVF-RTchla) \\
\hline All & 0.241 & 0.1 & 0.748 & $525(15.1-11.8)$ \\
L1 All & 0.254 & 0.075 & 0.840 & $124(14.8-11.8)$ \\
L2 All & 0.224 & 0.098 & 0.810 & $113(13.4-8.5)$ \\
L3 All & 0.165 & 0.154 & 0.805 & $65(8.6-6.2)$ \\
\hline
\end{tabular}

lagoon stations, the ratio was always low (around 0.10). The mean chl $c_{1+2}$ ratio $\left(c_{12} / a\right)$ was higher in the ocean than in the lagoon during Leg1. It did not exhibit important variations between Leg1 (0.097) and Leg3 (0.104). Nevertheless, the slight increase was associated with an increase of the lagoon ratios (Leg1: 0.080; Leg2: 0.086; Leg3: 0.104) and a decrease in the oceanic ratios (Leg1: 0.119; Leg2 and Leg3: 0.106).

The PE concentration ranged from 0.06 to $2.6 \mu \mathrm{g} \mathrm{L}^{-1}$ (mean $0.66 \mu \mathrm{g} \mathrm{L}^{-1}$ ). Maximum values were observed at the lagoon stations (T4-T7) during Leg1. The PE excitation spectra generally suggested dominance by Synechococcus populations. Nevertheless, some stations (essentially oceanic) showed Trichodesmium thiebautii to be dominant in the superficial layer. At the surface, an eleven fold increase of PE concentration was observed between the horn reefs (T21-T23: Table 4) whereas this concentration remained relatively constant in the lagoon. Furthermore, the PUB/PEB ratio, and consequently the relative importance of the high-PUB Synechococcus population, increased everywhere throughout the sampling period (Table 4).

In New Caledonian waters, the phytoplankton community can be regarded as a combination of three main groups, Chlorophytes, Chromophytes, and Cyanobacteria, each of them represented by one accessory pigment, chl $b$, chl $\left(c_{1}+c_{2}\right)$ and PE, respectively (Neveux et al., 2009). Linear multiregression of Tchl $a$ vs. (chl $b, \operatorname{chl} c_{1+2}$, PE) explained more than $94 \%$ of the Tchl $a$ variance and calculated partial regression coefficient (Table 5) allowed for estimates of the mean relative contribution of the three populations to the global Tchl $a$ concentration with a good confidence. During Leg1, mean contributions to Tchl $a$ were $41 \%$ for Chromophytes, $11 \%$ for Chlorophytes and $11.7 \%$ for Cyanobacteria, but mean residual value were high (36\%). During Leg2, the percentage slightly increased for all populations which resulted in a reduction of the residual part of the multiregression (28\%). The inverse of the partial regression coefficient represents the mean estimate of accessory pigment/Tchl $a$ ratio in the three populations (Table 5).

\subsection{Phytoplankton populations and relationships with pigment concentrations}

Based on cellular RALS and fluorescence properties, four classical populations were discriminated by flow cytometry: Prochlorococcus (proc), Synechococcus (syn) and two eukaryote groups, the smallest being assimilated to picoeukaryotes (peuK) and the largest to nanoeukaryotes (neuK). At the surface, transition from Leg1 to Leg3 showed a mean 2-3 fold increase of the eukaryotic populations in the sampling area; the increase was maximum between the horns (by a factor of 6 for picoeukaryotes) and generally more pronounced in the ocean than in the lagoon (Table 6). Similar patterns were observed for the Synechococcus population in the ocean and between the horns, but not in the lagoon. Prochlorococcus exhibited a $<2$ fold increase between Leg1 and Leg3. From Leg1 to Leg3, the calculation of the mean cell concentration in the water column (and limited to the 0$80 \mathrm{~m}$ layer for oceanic stations) showed relatively lower population increases. For example, between the horns, the relative change in mean cell concentration at the surface $(2 \mathrm{~m})$ was $6.41,3.59,1.05$ and 8.21 for peuK, neuK, proc and syn, respectively; on average for the 0 $80 \mathrm{~m}$ water column, it was 3.12, 2.74, 0.57 and 4.25 .

We observed linear relationships between the red fluorescence of the total population of Synechococcus, weighted by the PUB/PEB ratio $\left(\mathrm{FrT}_{\text {syn }}=\right.$ cell number $\times$ cellular fluorescence $\left./ \mathrm{PUB} / \mathrm{PEB}\right)$, and the phycoerythrin concentration in sea water $\left(R^{2}=0.91 ; n=269\right)$. According to their fluorescence, it was possible to distinguish at least two populations (bright and dim) of Synechococcus in 145 out of 269 samples. Between the reef horns, the eleven-fold increase of PE concentration was concomitant with a 34 fold increase of FrT $\mathrm{Fyn}_{\text {syn }}$. This latter resulted mainly from a seven fold increase of cell number between Leg1 and Leg2 whereas it was more related to cellular 
Table 4

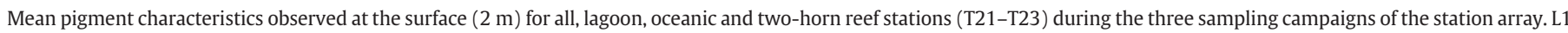
to L3 = Leg 1 to Leg 3. Data reported as mean (CV).

\begin{tabular}{|c|c|c|c|c|c|c|c|}
\hline \multirow[t]{2}{*}{ Samples } & \multirow{2}{*}{$\begin{array}{l}\text { Cruise } \\
\text { leg }\end{array}$} & \multirow{2}{*}{$\frac{b / a}{\%}$} & \multirow{2}{*}{$\frac{c_{1+2} / a}{\%}$} & \multirow{2}{*}{$\frac{\mathrm{Pa} / a}{\%}$} & \multirow{2}{*}{$\frac{\mathrm{dva}}{\%}$} & \multirow{2}{*}{$\frac{P E}{\mu g L^{-1}}$} & \multirow[t]{2}{*}{ PUB/PEB } \\
\hline & & & & & & & \\
\hline \multirow[t]{3}{*}{ All } & L1 & $12.1(18.9)$ & $10.3(24.0)$ & $4.4(40.0)$ & $28.7(55.7)$ & $0.48(110)$ & $1.14(23.6)$ \\
\hline & $\mathrm{L} 2$ & $13.3(37.0)$ & $9.7(27.3)$ & $6.1(40.6)$ & $20.4(62.9)$ & $0.44(63.6)$ & $1.29(19.0)$ \\
\hline & L3 & $17.5(34.5)$ & $10.4(18.1)$ & $6.5(29.4)$ & $16.2(52.9)$ & $0.83(51.8)$ & 1.57 (11.1) \\
\hline \multirow[t]{3}{*}{ Lagoon } & L1 & $12.4(19.1)$ & $8.0(14.4)$ & $4.2(45.9)$ & $12.8(77.3)$ & $0.88(66.4)$ & $1.11(19.0)$ \\
\hline & L2 & 15.7 (36.4) & $8.6(16.8)$ & $5.3(28.5)$ & $13.8(51.4)$ & $0.59(51.9)$ & $1.43(9.5)$ \\
\hline & L3 & $18.5(36.1)$ & $10.4(10.3)$ & 7.1 (25.9) & $13.2(51.6)$ & $0.87(45.5)$ & $1.58(9.3)$ \\
\hline \multirow[t]{3}{*}{ Ocean } & L1 & $11.8(18.5)$ & 11.9 (14.3) & $4.6(36.7)$ & $40.1(17.6)$ & $0.17(48.2)$ & 1.17 (26.7) \\
\hline & $\mathrm{L} 2$ & $11.4(28.5)$ & $10.6(29.1)$ & $6.8(42.9)$ & $25.6(55.0)$ & $0.34(63.5)$ & $1.18(21.6)$ \\
\hline & L3 & $15.6(28.4)$ & $10.6(29.0)$ & $5.2(27.4)$ & $22.2(40.8)$ & $0.75(68.8)$ & $1.54(15.0)$ \\
\hline \multirow[t]{3}{*}{ T21-T23 } & L1 & $11.2(12.1)$ & $13.9(9.2)$ & $4.0(22.1)$ & $47.6(14.1)$ & $0.12(0.61)$ & $1.16(24.6)$ \\
\hline & $\mathrm{L} 2$ & $11.7(26.4)$ & $7.0(12.7)$ & $5.4(51.3)$ & $11.1(25.8)$ & $0.46(29.7)$ & $1.41(17.8)$ \\
\hline & L3 & $18.7(7.5)$ & $8.5(14.6)$ & $6.0(6.6)$ & $13.9(14.7)$ & $1.28(14.4)$ & $1.72(1.0)$ \\
\hline
\end{tabular}

fluorescence increase (factor 3 ) between Leg2 and Leg3. It was also possible to distinguish bright and dim Prochlorococcus. A linear relationship was observed between dv-chl a concentration, a chemotaxonomic marker of Prochlorococcus, and total red fluorescence of Prochlorococcus populations $\left(\mathrm{FT}_{\mathrm{proc}} ; R^{2}=0.69 ; n=304\right)$, but a $R^{2}$ of 0.84 was found for a multiregression $\mathrm{FT}_{\text {proc }} \mathrm{vs}(\mathrm{dv}-\mathrm{chl} a$ and dvchl $b$ ). This suggested that the bright population was rich in dv-chl $b$ (more excited by the laser beam of the flow cytometer).

The global red fluorescence of each population depends on light excitation. Flow cytometry (excitation $488 \mathrm{~nm}$ ) indicated a mean $( \pm$ SD) contribution to the fluorescence signal of 48.3 ( \pm 20.1 ), 20.4

\section{Table 5}

Linear multiregression between Tchl $a$ and photosynthetic accessory pigments for all data and each sampling of station array: chlorophyll $b(\mathrm{chl} b)$, chlorophyll $c_{1}+c_{2}\left(\operatorname{chl} c_{1}+\right.$ $c_{2}$ ) and phycoerythrin (PE). C1, C2, C3 represent the partial regression coefficients for chl $b$, chl $c_{1}+c_{2}$ and PE, respectively. $\mathrm{K}$ is the residual Tchl $a$ when accessory pigments are null. The inverse of $\mathrm{C} 1, \mathrm{C} 2$, and $\mathrm{C} 3$ represents the mean estimate of the different pigment/ Tchl $a$ ratios. $R^{2}=$ determination coefficient; $n=$ sample number. L1 to L3 $=$ Leg 1 to Leg 3 .

\begin{tabular}{|c|c|c|c|c|c|c|c|}
\hline & Coefficient & $\begin{array}{l}\text { Standard } \\
\text { deviation }\end{array}$ & $t$-ratio & $p$ & $R^{2}$ & $n$ & $\begin{array}{l}\text { Pigment ratio } \\
\text { range estimates }\end{array}$ \\
\hline All samples & & & & & 95.6 & 276 & \\
\hline K & 0.087 & 0.004 & 19.95 & 0.0000 & & & \\
\hline $\mathrm{C} 1$ & 1.41 & 0.117 & 12.03 & 0.0000 & & & $0.61-0.85$ \\
\hline $\mathrm{C} 2$ & 4.15 & 0.259 & 16.05 & 0.0000 & & & $0.21-0.27$ \\
\hline C3 & 0.083 & 0.005 & 15.5 & 0.0000 & & & $10.8-13.7$ \\
\hline All surface (2 m) & & & & & 94.6 & 100 & \\
\hline K & 0.104 & 0.009 & 11.84 & 0.0000 & & & \\
\hline $\mathrm{C} 1$ & 2.19 & 0.266 & 8.23 & 0.0000 & & & $0.37-0.60$ \\
\hline $\mathrm{C} 2$ & 2.56 & 0.728 & 3.52 & 0.0007 & & & $0.25-0.88$ \\
\hline C3 & 0.082 & 0.012 & 7.07 & 0.0000 & & & $9.5-17.1$ \\
\hline All $\geq 15 \mathrm{~m}$ depth & & & & & 96.6 & 176 & \\
\hline K & 0.076 & 0.005 & 14.82 & 0.0000 & & & \\
\hline $\mathrm{C} 1$ & 1.20 & 0.121 & 9.89 & 0.0000 & & & $0.70-1.04$ \\
\hline $\mathrm{C} 2$ & 4.78 & 0.260 & 18.38 & 0.0000 & & & $0.19-0.23$ \\
\hline C3 & 0.078 & 0.006 & 13.77 & 0.0000 & & & $11.1-15.1$ \\
\hline L1 (all) & & & & & 97.0 & 80 & \\
\hline K & 0.082 & 0.006 & 13.35 & 0.0000 & & & \\
\hline $\mathrm{C} 1$ & 1.01 & 0.348 & 2.89 & 0.0050 & & & $0.59-3.05$ \\
\hline $\mathrm{C} 2$ & 5.24 & 0.752 & 6.97 & 0.0000 & & & $0.15-0.27$ \\
\hline C3 & 0.071 & 0.007 & 9.91 & 0.0000 & & & $11.8-17.5$ \\
\hline L2 (all) & & & & & 95.5 & 91 & \\
\hline K & 0.077 & 0.008 & 9.46 & 0.0000 & & & \\
\hline $\mathrm{C} 1$ & 0.90 & 0.217 & 4.15 & 0.0001 & & & $0.75-2.11$ \\
\hline $\mathrm{C} 2$ & 5.04 & 0.388 & 12.97 & 0.0000 & & & $0.17-0.23$ \\
\hline C3 & 0.127 & 0.015 & 8.3 & 0.0000 & & & $6.4-10.2$ \\
\hline L3 (all) & & & & & 96.3 & 57 & \\
\hline K & 0.120 & 0.012 & 9.81 & 0.0000 & & & \\
\hline $\mathrm{C} 1$ & 1.55 & 0.197 & 7.90 & 0.0000 & & & $0.52-0.86$ \\
\hline $\mathrm{C} 2$ & 2.94 & 0.604 & 4.87 & 0.0000 & & & $0.24-0.57$ \\
\hline $\mathrm{C} 3$ & 0.079 & 0.009 & 9.19 & 0.0000 & & & $10.3-16.3$ \\
\hline
\end{tabular}

a $95 \%$ confidence limits $=1 /$ ( coefficient \pm Standard deviation $* 1.96)$.
$( \pm 7.7), 21.6( \pm 9.8)$ and $9.6( \pm 10.0) \%$ for syn, peuK, neuK and proc, respectively. IVF was measured with an excitation light at $455 \mathrm{~nm}$. By use of multiregression, $74.5 \%$ of the variance of IVF $(n=345)$ could be explained by a linear combination of the total red fluorescence of each population. However, the relative contribution of syn to the fluorescence signal appeared strongly reduced $(7.5 \pm 4.8 \%)$ whereas that of eukaryotes increased (peuK: $50.2 \pm 10.3 \%$; neuK: $32.3 \pm 10.5 \%$ ) and that of Prochlorococcus remained at similar relative level (10.1 $\pm 7.9 \%)$. The difference can be explained by higher light absorption by PE-containing Cyanobacteria at the wavelength of $488 \mathrm{~nm}$ than at $455 \mathrm{~nm}$. The residual could reflect the relative influence of the $>10 \mu \mathrm{m}$ phytoplankton cells on the IVF signal.

\subsection{In vivo fluorescence, phytoplankton growth rate and grazing rate at $25 \mathrm{~h}$ time series stations}

\subsubsection{T4 time series}

Time series started at high tide (8:00 AM, 18 February 2007). Temperature, salinity and density $\left(\sigma_{\theta}\right)$ varied in a relatively small range at station $\mathrm{T} 4$ where the bottom was at $40 \mathrm{~m}$ depth (Table 7 ). This station was relatively poor in nutrients (Table 7 ) with a mean N/P ratio between 5 and 6 depending on the three different sampling depths. Slight stratification developed in the morning (Fig. 5) during the ebb tide and remained until homogenisation of the water column that occurred in the late afternoon (6-7 PM) just before next high slack water. Fmax and Fint (15-35 m) showed similar variations. They increased during the light period (I phase) until 4 PM then decreased

\section{Table 6}

Mean cell abundance (cells $\mathrm{mL}^{-1}$ ) of the two eukaryotes populations (picoeukaryotes $=$ peuK; nanoeukaryotes $=$ neuK) and Cyanobacteria (Prochlorococcus $=$ proc: Synechococcus $=$ syn) observed at the surface $(2 \mathrm{~m})$ for all, lagoon, oceanic and two horn reef stations (T21-T23) during the three samplings of the station network. Mean abundance ratio between two samplings (Lx/Ly). L1 to L3 = Leg 1 to Leg 3. Data reported as mean $(\mathrm{CV})$.

\begin{tabular}{lllllr}
\hline Samples & Cruise leg & peuK & neuK & proc & \multicolumn{1}{l}{ syn } \\
\hline \multirow{2}{*}{ Total } & L1 & $2049(63.2)$ & $236(52.8)$ & $40,486(43.2)$ & $61,771(106)$ \\
& L2 & $4121(66.2)$ & $315(44.0)$ & $46,906(64.0)$ & $68,653(87.0)$ \\
& L3 & $4892(54.6)$ & $499(36.2)$ & $63,190(51.7)$ & $67,732(50.9)$ \\
Ocean & L1 & $1263(33.7)$ & $159(43.1)$ & $45,725(41.9)$ & $19,956(77.8)$ \\
& L2 & $3309(67.9)$ & $271(45.1)$ & $49,193(55.2)$ & $49,656(87.7)$ \\
& L3 & $3916(86.6)$ & $366(56.8)$ & $78,958(18.0)$ & $73,611(68.1)$ \\
Lagoon & L1 & $3137(41.9)$ & $343(30.5)$ & $33,635(37.7)$ & $116,453(57.1)$ \\
& L2 & $5165(58.4)$ & $371(38.2)$ & $43,967(77.8)$ & $91,676(72.1)$ \\
T21-T23 & L3 & $5380(41.2)$ & $565(22.5)$ & $55,307(66.4)$ & $65,212(41.9)$ \\
& L1 & $1173(04.4)$ & $157(29.2)$ & $67,262(24.5)$ & $14,147(21.6)$ \\
& L2 & $6268(33.1)$ & $286(23.9)$ & $35,740(61.1)$ & $99,431(40.6)$ \\
& L3 & $7519(06.1)$ & $563(06.0)$ & $70,469(24.9)$ & $116,216(21.9)$ \\
\hline
\end{tabular}


Table 7

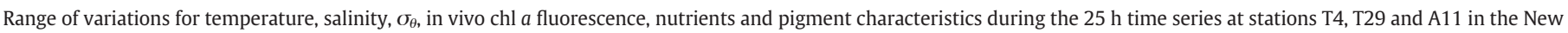
Caledonia Lagoon. For pigment and nutrients, data are presented for the three sampling depths (D); C $=$ concentration.

\begin{tabular}{|c|c|c|c|c|c|c|c|}
\hline Parameter & Units & $\frac{D}{(\mathrm{~m})}$ & T4 $(n=25)$ & $\frac{D}{(\mathrm{~m})}$ & $\mathrm{T} 29(n=25)$ & $\frac{D}{(\mathrm{~m})}$ & A11 $(n=25)$ \\
\hline Temperature & ${ }^{\circ} \mathrm{C}$ & & 25.69-25.99 & & $20.93-25.65$ & & $24.40-25.93$ \\
\hline Salinity & & & $35.42-35.46$ & & $35.44-35.65$ & & $35.46-35.51$ \\
\hline Density $\left(\sigma_{\theta}\right)$ & & & $23.36-23.46$ & & $23.49-25.01$ & & $23.44-23.91$ \\
\hline Fluorescence & r.u. & & $0.6-2.1$ & & $0.5-2.6$ & & $0.4-2.5$ \\
\hline Bottom & $\mathrm{m}$ & & 40 & & 80 & & 55 \\
\hline \multirow[t]{3}{*}{$\mathrm{NO}_{3+2}\left(\right.$ mean $\left.\mathrm{NH}_{4}, n=5\right)$} & $\mu \mathrm{M}$ & 0 & $0.081 \pm 0.036(0.039)$ & 0 & $0.068 \pm 0.090(0.034)$ & 0 & $0.023 \pm 0.017(0.039)$ \\
\hline & & 20 & $0.088 \pm 0.051(0.042)$ & 40 & $0.53 \pm 0.31(0.037)$ & 30 & $0.030 \pm 0.020(0.067)$ \\
\hline & & 35 & $0.088 \pm 0.037(0.045)$ & 70 & $2.08 \pm 0.71(0.038)$ & 53 & $0.055 \pm 0.018(0.123)$ \\
\hline \multirow[t]{3}{*}{$\mathrm{PO}_{4}$} & $\mu \mathrm{M}$ & 0 & $0.016 \pm 0.006$ & 0 & $0.017 \pm 0.009$ & 0 & $0.032 \pm 0.022$ \\
\hline & & 20 & $0.016 \pm 0.006$ & 40 & $0.064 \pm 0.024$ & 30 & $0.041 \pm 0.010$ \\
\hline & & 35 & $0.017 \pm 0.006$ & 70 & $0.142 \pm 0.024$ & 53 & $0.065 \pm 0.009$ \\
\hline \multirow[t]{3}{*}{ Chl $a$} & $\mu \mathrm{g} \mathrm{L}^{-1}$ & 0 & $0.350-0.548$ & 0 & $0.174-0.416$ & 0 & $0.213-0.273$ \\
\hline & & 20 & $0.355-0.673$ & 40 & $0.344-0.745$ & 30 & $0.250-0.502$ \\
\hline & & 35 & $0.345-0.649$ & 70 & $0.100-0.366$ & 53 & $0.304-0.457$ \\
\hline \multirow[t]{6}{*}{ Chl $b$} & $C\left(\mu g \mathrm{~L}^{-1}\right)$ & 0 & $0.064-0.117$ & 0 & $0.036-0.077$ & 0 & $0.024-0.042$ \\
\hline & $b / a$ ratio & & $0.16-0.22(0.14-0.19)^{a}$ & & $0.15-0.22(0.13-0.18)^{a}$ & & $0.10-0.16(0.10-0.16)^{a}$ \\
\hline & C. $\left(\mu \mathrm{g} \mathrm{L}^{-1}\right)$ & 20 & $0.070-0.151$ & 40 & $0.091-0.203$ & 20 & $0.036-0.103$ \\
\hline & $b / a$ ratio & & $0.18-0.22(0.15-0.20)^{a}$ & & $0.22-0.30(0.16-0.24)^{a}$ & & $0.14-0.21(0.13-0.20)^{\mathrm{a}}$ \\
\hline & $C\left(\mu \mathrm{g} \mathrm{L}^{-1}\right)$ & 35 & $0.065-0.143$ & 70 & $0.029-0.105$ & 53 & $0.067-0.106$ \\
\hline & $b / a$ ratio & & $0.18-0.22(0.16-0.20)^{a}$ & & $0.28-0.33(0.20-0.23)^{a}$ & & $0.22-0.27(0.18-0.22)^{a}$ \\
\hline \multirow[t]{6}{*}{ Chl $c_{1}+c_{2}$} & $C\left(\mu \mathrm{g} \mathrm{L}^{-1}\right)$ & 0 & $0.033-0.050$ & 0 & $0.015-0.036$ & 0 & $0.015-0.024$ \\
\hline & $c_{1}+2 / a$ ratio & & $0.08-0.10$ & & $0.07-0.09$ & & $0.07-0.09$ \\
\hline & $\mathrm{C}\left(\mu \mathrm{g} \mathrm{L}^{-1}\right)$ & 20 & $0.034-0.061$ & 40 & $0.04-0.078$ & 20 & $0.024-0.063$ \\
\hline & $c_{1}+2 / a$ ratio & & $0.09-0.10$ & & $0.09-0.12$ & & $0.10-0.14$ \\
\hline & C. $\left(\mu \mathrm{g} \mathrm{L}^{-1}\right)$ & 35 & $0.032-0.066$ & 70 & $0.015-0.044$ & 53 & $0.041-0.070$ \\
\hline & $c_{1}+2 / a$ ratio & & $0.09-0.10$ & & $0.11-0.16$ & & $0.12-0.16$ \\
\hline \multirow[t]{6}{*}{ Dv-chl $a$} & $C\left(\mu \mathrm{g} \mathrm{L}^{-1}\right)$ & 0 & $0.045-0.075$ & 0 & $0.042-0.091$ & 0 & $0.007-0.019$ \\
\hline & $\% \mathrm{dv}-\mathrm{chl} a$ & & $9.6-15.5$ & & $14.5-20.7$ & & $2.7-7.6$ \\
\hline & $C\left(\mu \mathrm{g} \mathrm{L}^{-1}\right)$ & 20 & $0.049-0.092$ & 40 & $0.087-0.181$ & 20 & $0.021-0.047$ \\
\hline & $\%$ dv-chl $a$ & & $10.0-15.5$ & & $16.3-24.8$ & & $5-12.8$ \\
\hline & $C\left(\mu \mathrm{g} \mathrm{L}^{-1}\right)$ & 35 & $0.054-0.083$ & 70 & $0.044-0.095$ & 53 & $0.070-0.104$ \\
\hline & $\%$ dv-chl $a$ & & $10.9-15.1$ & & $19.7-32.4$ & & $15.9-23.3$ \\
\hline \multirow{3}{*}{$\begin{array}{l}\text { Mean dv-chl a } \\
( \pm \text { STD }) \text { in Prochlorococcus } \\
n=5\end{array}$} & fg cell ${ }^{-1}$ & 0 & $1.03 \pm 0.18$ & 0 & $0.87 \pm 0.24$ & 0 & $0.78 \pm 0.34$ \\
\hline & & 20 & $1.13 \pm 0.36$ & 40 & $1.19 \pm 0.33$ & 30 & $1.02 \pm 0.28$ \\
\hline & & 35 & $1.02 \pm 0.25$ & 70 & $2.08 \pm 0.13$ & 53 & $1.35 \pm 0.27$ \\
\hline \multirow{3}{*}{ Mean PE $( \pm$ STD $)$ in Synechococcus $n=5$} & fg cell ${ }^{-1}$ & 0 & $14.34 \pm 3.25$ & 0 & $6.23 \pm 2.02$ & 0 & $6.28 \pm 1.29$ \\
\hline & & 20 & $16.03 \pm 2.52$ & 40 & $18.13 \pm 2.95$ & 30 & $15.41 \pm 7.24$ \\
\hline & & 35 & $16.36 \pm 6.39$ & 70 & $23.16 \pm 3.69$ & 53 & $21.85 \pm 4.71$ \\
\hline
\end{tabular}

${ }^{\text {a }}$ In brackets ratio Chl $b /$ Tchl $a$ with Tchl $a=(\operatorname{Chl} a+\operatorname{Dv}-\operatorname{chl} a)$.

(Fig. 6). The decrease was sharper at the beginning as a consequence of homogenization. Grazing estimates for a $24 \mathrm{~h}$ period from the exponential regression during the decreasing phase of fluorescence (D phase) corresponded to a removal of nearly half the phytoplankton standing stock (Table 8). Assuming a constant grazing rate throughout the $24 \mathrm{~h}$ period, the phytoplankton overall growth rate estimate was slightly higher than one division per day as computed from the difference between daily I and D exponential regressions. Therefore, the balance was in favour of an increase of the phytoplankton standing stock from day to day. However, comparison of the fluorescence level at $24 \mathrm{~h}$ interval suggested a balance between phytoplankton growth and grazing. Growth rates and grazing, could also be assessed at 20 and $35 \mathrm{~m}$ depth from changes in the concentrations of various chlorophylls (see Table 8 for chl $a$ at $35 \mathrm{~m}$ ). However, the confidence in the grazing estimates was poor as indicated by the relatively low value of the determination coefficient. Based on dv-chl $a$, the Prochlorococcus gross growth rate ( 0.7 divisions per day) was lower than that of chl $a$-containing species (1.1-1.2 division per day).

The pigment ratios observed during the time series were similar at the three sampling depths suggesting that there was no important modification of the phytoplankton community structure (Table 7). Dv-chl $a$ concentration represented $10-15 \%$ of Tchl $a$ for a Prochlorococcus population of $50-70 \cdot 10^{3}$ cells $\mathrm{mL}^{-1}$. Synechococcus abundance varied from $65 \cdot 10^{3}$ to $135 \cdot 10^{3}$ cells $\mathrm{mL}^{-1}$ and that of picoeukaryotes from $3.2 \cdot 10^{3}$ to $8.8 \cdot 10^{3}$ cells $\mathrm{mL}^{-1}$. The PUB/PEB ratio of PE was relatively high $(1.33 \pm 0.06)$ and $\mathrm{PE}$ concentration ranged from 1.02 - to $1.80 \mu \mathrm{g} \mathrm{L}^{-1}$ (mean $\pm \mathrm{SD}=1.31 \pm 0.21 ; n=5$ ). On the basis of a PE/chl $a$ ratio of 14 (Neveux et al., 2009) and a PE content of $14-16 \mathrm{fg} \mathrm{cell}^{-1}$ in Synechococcus (Table 7), the relative contribution of Synechococcus to the Tchl a concentration in the global community was $15-20 \%$.

\subsubsection{T29 time series}

The time series started at low tide (3:45 AM, 21 February 2007). Physical parameters showed important water stratification (Table 7). An outstanding feature of this time series was the approximately $20 \mathrm{~m}$ oscillation of isotherms, isohalines, isopycnes and IVF maximum between low and high tide. The isolines deepened until mid-flood then came back to their initial level (Fig. 7). Fmax showed a minimum at 5:30 AM (near sunrise, 5:45 AM) and increased until 3:00 PM, then decreased until the end of the time series. The exponential regressions calculated from the I and D phases of Fmax suggested a balance between growth and grazing on a daily scale (Table 8 ). According to Fint, the balance would be in favour of grazing losses and consequently in the reduction of the phytoplankton standing stock. Nevertheless, like for site T4, the fluorescence levels at the beginning and the end of the time series were similar. $\mathrm{NO}_{3+2}$ fluctuations at 40 and $70 \mathrm{~m}$ followed water oscillations and showed an important enrichment at this shelf reef station (Fig. 8). The mean N/P ratio increased with depth, and reached a value near the Redfield ratio at $70 \mathrm{~m} \mathrm{(2.7}$ at $0 \mathrm{~m}, 7.3$ at $40 \mathrm{~m}, 14.4$ at $70 \mathrm{~m}$ ). Because of the vertical 

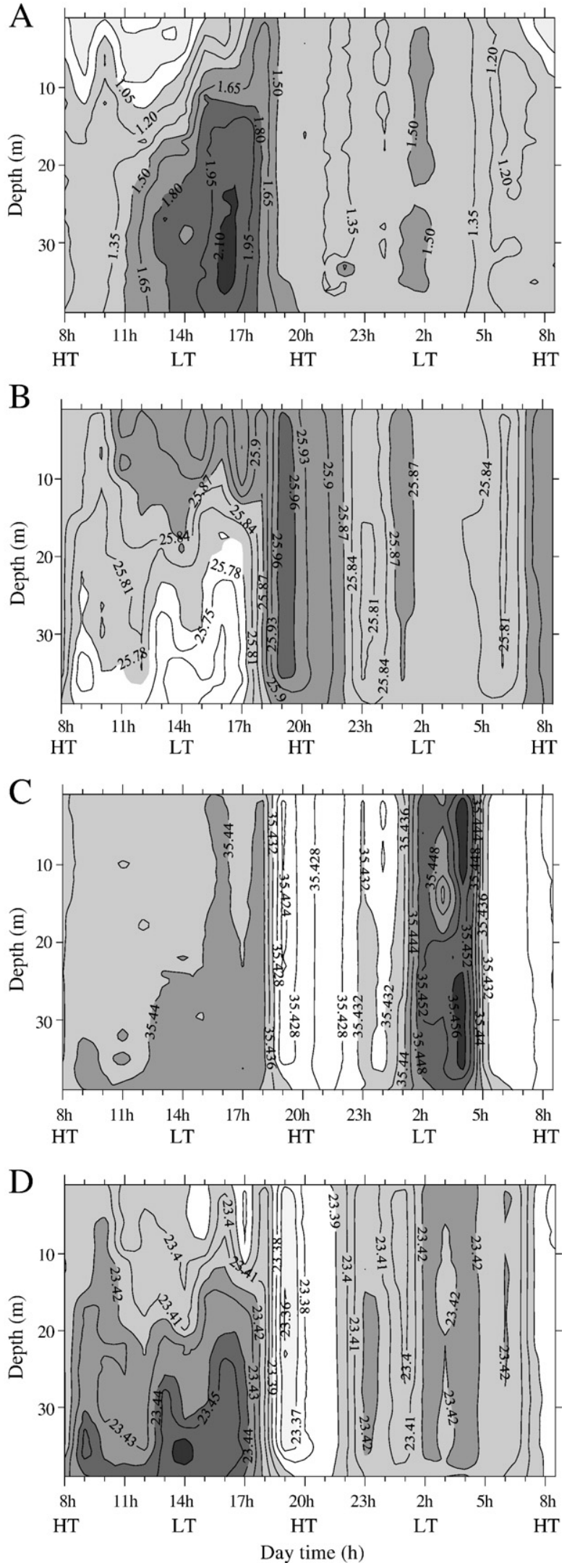

Fig. 5. Time series at the station T4. A) In vivo chlorophyll $a$ fluorescence (r.u.), B) temperature $\left.\left({ }^{\circ} \mathrm{C}\right), \mathrm{C}\right)$ salinity, D) density $\left(\sigma_{\theta}\right)$; HT $=$ high tide; LT = low tide. oscillations, it was not possible to measure phytoplankton growth and grazing rates from extracted pigments at fixed depths. The pigment ratios increased with depth as expected in stratified waters (Table 7). The Prochlorococcus abundance was generally higher than at T4 in the 0-40 m layer $\left(64-117 \cdot 10^{3}\right.$ cells $\left.\mathrm{mL}^{-1}\right)$ but decreased at $70 \mathrm{~m}(23-$ $30 \cdot 10^{3}$ cells $\mathrm{mL}^{-1}$ ). However, the percentage of $\mathrm{dv}$-chl $a$, and consequently the relative importance of Prochlorococcus in the community, was more important at $70 \mathrm{~m}$ (30\%) than above (15$20 \%)$. Other picoplanktonic population abundances decreased with depth (for Synechococcus: $54-167 \cdot 10^{3}$ cells $\mathrm{mL}^{-1}$ in the $0-40 \mathrm{~m}$ layer against $6-10 \cdot 10^{3}$ cells $\mathrm{mL}^{-1}$ at $70 \mathrm{~m}$; for picoeukaryotes: $4.2-$ $7.7 \cdot 10^{3}$ cells $\mathrm{mL}^{-1}$ and $1.3-1.7 \cdot 10^{3}$ cells $\mathrm{mL}^{-1}$, respectively). The PE concentrations were slightly lower $(0.72 \pm 0.45)$ than at T4 while the PUB/PEB ratio was similar at the surface (1.39) and higher at 40 and $70 \mathrm{~m}$ (1.62). A clear increase with depth of the mean dv-chl $a$ per Prochlorococcus cell and mean PE per Synechococcus cell were also observed.

\subsubsection{A11 time series}

This time series also started at low tide (11:40 PM, 28 February 2007). Stratification of the water column occurred over sampling period. Isolines showed slight oscillations (Fig. 9). Waters were very poor in $\mathrm{NO}_{3}+2$ with a very low $\mathrm{N} / \mathrm{P}$ ratio (2-3). $\mathrm{NH}_{4}$ was the main source of inorganic nitrogen and increased with depth (Table 7). There was also a significant increase in IVF for the 30-50 m layer from sunrise to around 3 PM (Fig. 6). Exponential regressions between Fmax (or Fint) and time indicated a positive imbalance between phytoplankton gross growth rate (1.25 division per day) and consumer activity (Table 8 ). The estimated gross growth and grazing rates from the concentration of chl $a$ extracted gave values comparable to that obtained from IVF. However, the coefficient of determination of the exponential regression for grazing estimates was again weak and relatively imprecise. The Tchl $a$ maximum was always between 30 and $53 \mathrm{~m}$ depth. The Prochlorococcus abundance (15.4 \pm $6.7 \cdot 10^{3}$ cells $\mathrm{mL}^{-1}$ at $0 \mathrm{~m} ; 34.1 \pm 9.4 \cdot 10^{3}$ cells $\mathrm{mL}^{-1}$ at $30 \mathrm{~m} ; 68.4 \pm$ $12.9 \cdot 10^{3}$ cells $\mathrm{mL}^{-1}$ at $53 \mathrm{~m}$ ) as well as the dv-chl $a$ concentrations and the relative percentage of dv-chl $a$ increased with depth (Table 7). On the contrary, the abundance of Synechococcus decreased with depth like at T29 $\left(117.8 \pm 33.8 \cdot 10^{3}\right.$ cells $\mathrm{mL}^{-1}$ at $0 \mathrm{~m} ; 68.0 \pm$ $18.3 \cdot 10^{3}$ cells $\mathrm{mL}^{-1}$ at $30 \mathrm{~m} ; 29.4 \pm 5.4 \cdot 10^{3}$ cells $\mathrm{mL}^{-1}$ at $53 \mathrm{~m}$ ). The PE concentration showed little variation with depth and was similar to that at T29 $\left(0.77 \pm 0.20 \mu \mathrm{g} \mathrm{L}^{-1}\right)$. The PUB/PEB ratio $(1.27 \pm$ 0.06 ) was slightly lower than at the other fixed stations. However, stratification lead to increases in pigment ratio and pigment per cell with depth (Table 7).

\section{Discussion}

4.1. South east trade winds and enrichment of southern New Caledonian waters

When southeast trade winds blow, the water cools by up to $5{ }^{\circ} \mathrm{C}$, and the cooling can be observed all along the SW barrier reef and between the horns of the southern lagoon of New Caledonia (Hénin and Cresswell, 2005). The trade winds, approximately parallel to the NW-SE orientation of New Caledonia, cause upwelling of water that could originate from around one hundred meters deep at their maximum intensity (Hénin and Cresswell, 2005). To what extent this upwelling can enrich the euphotic zone in nutrients and stimulate the biological activity around New Caledonia remains an important question for environmental as well as economic point of view. Previous results showed occasional in situ surface enrichment related to trade winds near the barrier reef (Neveux et al., 2009; Ganachaud et al., in press); it was accompanied by an enhancement of Tchl $a$ concentration which could be detected by satellite images (Dupouy, 1990; Ganachaud et al., in press). During Echolag, four stations were 

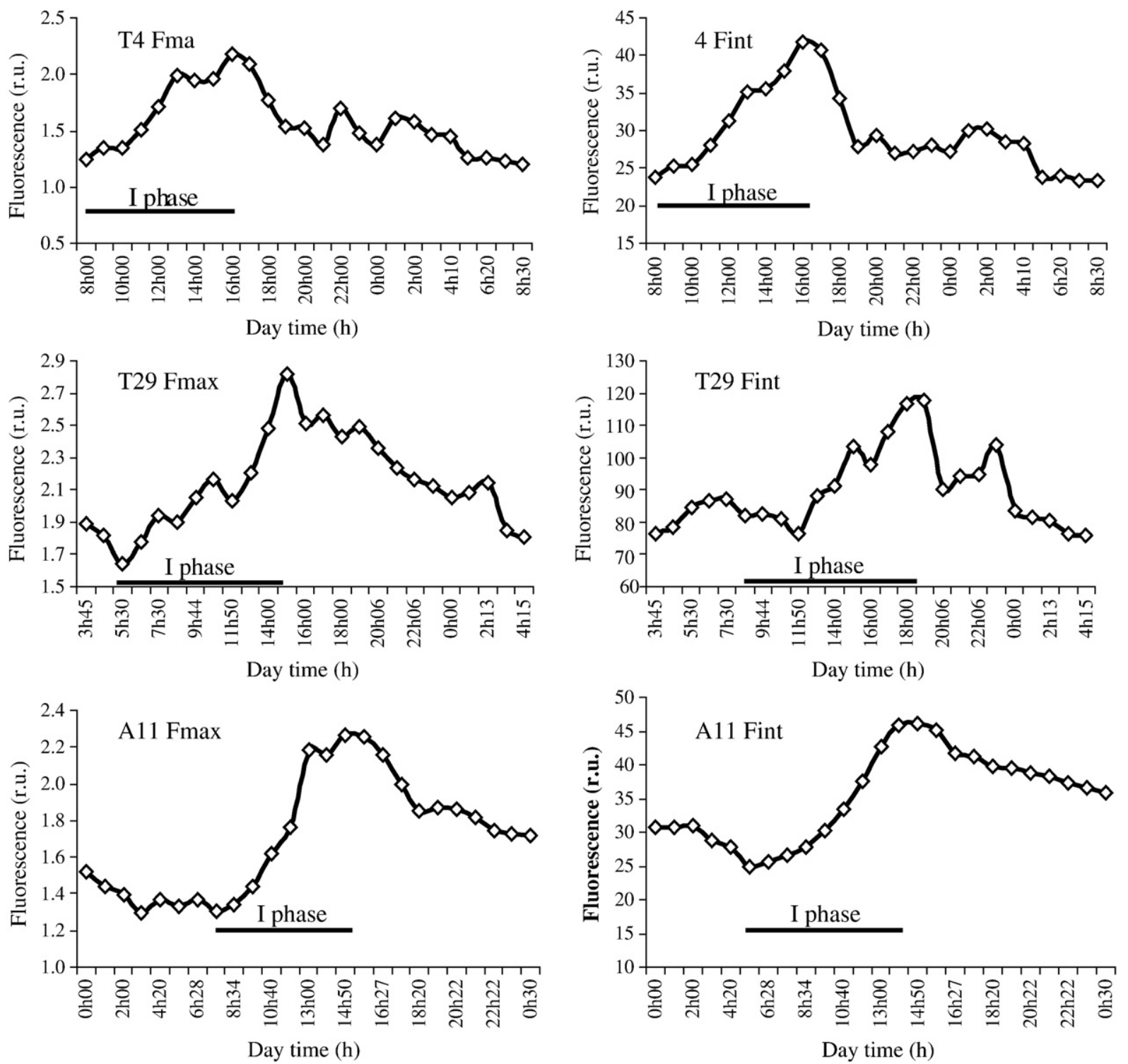

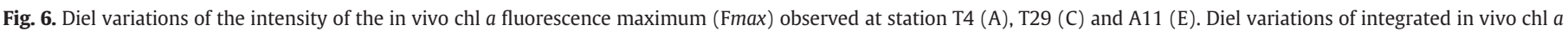
fluorescence (Fint) in the deep layer at station T4 (B, 15-35 m layer), T29 (D, 15-75 m layer) and A11 (F, 30-53 m layer).

sampled along the barrier reef (T10, T11, T27 and T28). At these stations, no major changes in nutrient concentration were observed in the $0-60 \mathrm{~m}$ layer when comparing the three sampling dates. Nevertheless, the Tchl $a$ concentrations in the 0-80 m layer appeared slightly higher during Leg2 at T10, T11 and during Leg3 at T27, T28. The $2{ }^{\circ} \mathrm{C}$ lowering of the temperature suggested that the upwelled waters originated from 50 to $60 \mathrm{~m}$ and consequently from a layer above the nitracline which was located beyond $60 \mathrm{~m}$ depth.

The Echolag cruise was the first opportunity to examine more precisely what happens between the horn reefs during an event of relatively strong trade winds. These trade winds lead to SW-NE temperature (positive) and salinity (negative) gradients across the horn reef. Trade wind effects are more apparent in the mean variations for the entire study area than for individual stations. The mean variations throughout the sampling area are certainly more representative of the effect of trade winds than variations observed at a given station. From Leg1 to Leg3, an increase of mean pigment concentration, picoeukaryotes and Cyanobacteria abundance was measured. The $25 \mathrm{~h}$ study at site T29 suggested the presence of semidiurnal tidally generated internal waves which could enhance phytoplankton productivity and dynamics since it moved the deep chl $a$ maxima (DCM) and associated nutrients to shallower depths as solar irradiance at the surface increased. This observation appeared very similar to tidally-induced upwelling of cold Coral Sea waters on the continental shelf of the Great Barrier Reef (Thomson and Wolanski, 1984). Thomson and Wolanski (1984) explain the upwelling in terms of fluid withdrawal mechanisms in which nutricline is drawn onto the shelf during flood. The enrichment, related to internal waves of the mid and bottom waters of the southern continental shelf of New Caledonia was certainly reinforced by the trade winds through a general rise of the thermocline-nitracline and the DCM closer to the surface; colder richer waters were observed until T5-T6 during Leg2. This enrichment could favour significantly the development of coral reefs via general water circulation on the shelf and in the southern lagoon as observed in the Great Barrier Reef ecosystems (Andrews and Gentien, 1982). Further information is required to specify the precise enrichment mechanisms above the reef shelf. It will be important to quantify more precisely at different time scales the nutrient fluxes related to upwelled waters between the two horns and the impact of climatic conditions on these fluxes and coral development. 
Table 8

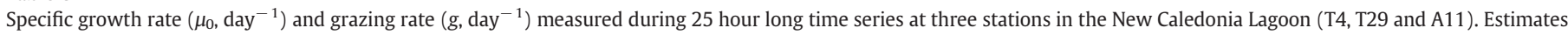

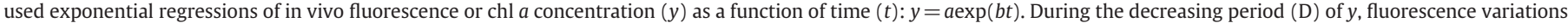

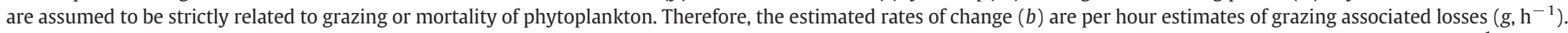

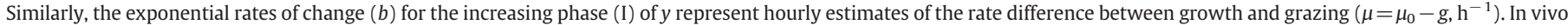

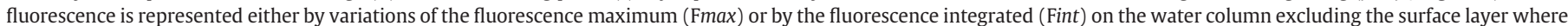

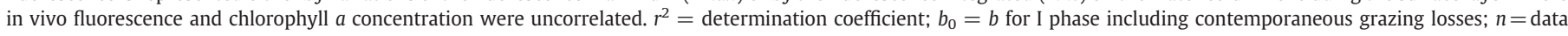
number; div. = division number; $c=$ half reduction number related to grazing.

\begin{tabular}{|c|c|c|c|c|c|c|c|c|}
\hline D phase & $n$ & $r^{2}$ & $a$ & $b\left(g, \mathrm{~h}^{-1}\right)$ & & $g\left(\mathrm{~d}^{-1}\right)$ & $c\left(d^{-1}\right)$ & D period ${ }^{a}$ \\
\hline T4 Fmax & 17 & 0.70 & 1.95 & -0.0283 & & -0.68 & 0.98 & $16 \mathrm{~h}-8.5 \mathrm{~h}$ \\
\hline T4 Fint (15-35 m) & 17 & 0.66 & 36.77 & -0.0275 & & -0.66 & 0.95 & $16 \mathrm{~h}-8.5 \mathrm{~h}$ \\
\hline $\mathrm{T} 4 \mathrm{chl}$ a $35 \mathrm{~m}$ & 17 & 0.45 & 0.542 & -0.0206 & & -0.49 & 0.71 & $16 \mathrm{~h}-8.5 \mathrm{~h}$ \\
\hline T29 Fmax & 11 & 0.92 & 2.79 & -0.029 & & -0.69 & 0.99 & $15 \mathrm{~h}-4.25 \mathrm{~h}$ \\
\hline T29 Fint (15-75 m) & 10 & 0.73 & 110.76 & -0.0399 & & -0.96 & 1.39 & $19 \mathrm{~h}-4.25 \mathrm{~h}$ \\
\hline A11 Fmax & 11 & 0.91 & 2.30 & -0.0299 & & -0.72 & 1.04 & $14.8 \mathrm{~h}-0.5 \mathrm{~h}$ \\
\hline A11 Fint $(30-53 \mathrm{~m})$ & 10 & 0.94 & 45.94 & -0.0234 & & -0.56 & 0.81 & $15.5 \mathrm{~h}-0.5 \mathrm{~h}$ \\
\hline A11 chl a $30 \mathrm{~m}$ & 10 & 0.24 & 0.46 & -0.0227 & & -0.54 & 0.78 & $15.5 \mathrm{~h}-0.5 \mathrm{~h}$ \\
\hline I phase & $n$ & $r^{2}$ & $a$ & $b\left(\mu, \mathrm{h}^{-1}\right)$ & $b_{0}\left(\mu_{0}, \mathrm{~h}^{-1}\right)$ & $\mu_{0}\left(\mathrm{~d}^{-1}\right)$ & $\operatorname{div} .\left(d^{-1}\right)$ & I period $^{\mathrm{a}}$ \\
\hline T4 Fmax & 9 & 0.9 & 1.1509 & 0.0734 & 0.1017 & 0.81 & 1.17 & $8 \mathrm{~h}-16 \mathrm{~h}$ \\
\hline T4 Fint (15-35 m) & 9 & 0.98 & 21.54 & 0.073 & 0.1009 & 0.81 & 1.17 & $8 \mathrm{~h}-16 \mathrm{~h}$ \\
\hline T4 chl $a 35 \mathrm{~m}$ & 9 & 0.90 & 0.348 & 0.0765 & 0.0971 & 0.78 & 1.12 & $8 \mathrm{~h}-16 \mathrm{~h}$ \\
\hline T29 Fmax & 10 & 0.89 & 1.59 & 0.049 & 0.078 & 0.70 & 1.01 & $5.5 \mathrm{~h}-15 \mathrm{~h}$ \\
\hline T29 Fint (15-75 m) & 11 & 0.86 & 72.74 & 0.0427 & 0.0726 & 0.73 & 1.05 & $8.7 \mathrm{~h}-19 \mathrm{~h}$ \\
\hline A11 Fmax & 10 & 0.91 & 1.16 & 0.0732 & 0.1031 & 0.93 & 1.34 & $6.5 \mathrm{~h}-15.5 \mathrm{~h}$ \\
\hline A11 Fint $(30-53 \mathrm{~m})$ & 10 & 0.96 & 21.5 & 0.0364 & 0.079 & 0.92 & 1.33 & $5.3 \mathrm{~h}-14.8 \mathrm{~h}$ \\
\hline A11 chl a $30 \mathrm{~m}$ & 11 & 0.96 & & 0.0712 & 0.0939 & 0.94 & 1.36 & $5.3 \mathrm{~h}-15.5 \mathrm{~h}$ \\
\hline
\end{tabular}

a Data period used to calculate the $b$ coefficients.

\subsection{Spectrofluorometry and community structure}

To determine phytoplankton community structure, spectrofluorometry on crude extracts does not offer the same analytical capabilities as high performance liquid chromatography. Nevertheless, it is convenient for high frequency sampling and the information it can add about the community structure is useful for field studies. For hydrosoluble pigments, it provides both qualitative and quantitative information on the main phycobiliprotein-containing groups. Regarding liposoluble pigments, the most important use of spectrofluorometry in oligotrophic waters is to provide specific information on divinyl-chl $a$ concentration related to Prochlorococcus populations and its relative contribution to Tchl $a$ concentration. In the present study, the remaining Tchl $a$ (i.e. chl $a=$ monovinyl-chl $a$ ) was considered to belong to three major groups (Chlorophytes, Chromophytes and Cyanobacteria), each of these represented exclusively by one accessory pigment: chl $b$, chl $c_{1}+c_{2}$ or PE, respectively. Theoretically, this latter assumption is an approximation since a combination of chl $c_{2}$ and PE is found in Cryptophytes (Rowan, 1989). Nevertheless, during Echolag, the fluorescence excitation spectra of PE showed typical characteristics of Cyanobacteria-PE (most often Synechococcus sp. and sometimes Trichodesmium sp., Neveux et al., 2006). Fluorescence excitation spectra of Cryptophytes-PE are significantly different from that of Cyanobacteria (Rowan, 1989). No evidence of a significant proportion of Cryptophytes-PE was observed in our samples. Furthermore, a part of the chl $b$ could be associated with Prochlorococcus (Cyanobacteria) and not just the Chlorophytes. Considering that chl $b, \operatorname{chl} c_{1}+c_{2}$ and PE were independent variables that may explain variations of Tchl $a$, partial linear regression coefficients associated with each accessory pigment could be determined with high confidence. However, the residual part of the multiregression was relatively high contrary to that obtained in previous work in the SWL (Neveux et al., 2009). The residual fraction could be related to populations of Eustigmatophyceae (containing no accessory pigments) or/and coccoid Cyanobacteria containing phycocyanin as major phycobiliprotein (Rowan, 1989). Nevertheless, no evidence of these populations was observed in the present study or in previous ones (Neveux et al., 2009). Generally, the mean pigment ratio estimated from the partial regression coefficient is in agreement with that observed in cultures of the different groups and rather close to those obtained with the same techniques in the SWL $(0.55-0.61$ for Chlorophytes; $0.19-0.20$ for Chromophytes; $14-15$ for cyanobacteria: Neveux et al., 2009). However, the uncertainties represented by the $95 \%$ confidence limits of the pigment ratio estimates were sometimes high (for example, the chl $c_{1}+c_{2} / \mathrm{chl} a$ ratio related to Chromophytes in surface samples and chl $b /$ chl $a$ in Leg 1 samples, Table 5). For the $\mathrm{PE} / \mathrm{chl}$ a ratio, a lack of quantitative information on cultures prevents rigorous comparison with the results of multiregressions.

\subsection{Problems for the estimation of growth and grazing rates from in situ observations}

Globally, increases in pigment concentration and abundance of phytoplankton cells suggested an imbalance over a $24 \mathrm{~h}$ time scale between phytoplankton growth and grazing processes which then lead to increases in phytoplankton biomass. In the present study, a mean imbalance of 3-4\% per day would be sufficient to explain the relative mean increase of Tchl $a(33 \%)$ and chl $a(40 \%)$ between Leg1 and Leg2. However, measurement of instantaneous biomass does not represent an estimate of phytoplankton growth dynamics. The phytoplankton growth rate is essential to predict the quantity of organic material which is available to higher trophic levels in an ecosystem. Diel variations of IVF may be used to estimate in situ phytoplankton growth and grazing rates (Marra, 1997). However, to validate these in situ estimates, certain physical conditions must be met and IVF (or pigment) variations have to be compatible with a model relating chlorophyll synthesis and cell division.

\subsubsection{Hydrologic challenges}

In situ growth estimates assume that the fixed sampling position is included in a single large water body characterized by vertically similar and horizontally homogeneous distribution of phytoplankton standing stock and that processes are synchronous in the entire water body. In this case, time observations are independent of water advection. These conditions were reasonably met in upwelled HighNutrient Low-Chlorophyll (HNLC) waters of the equatorial Pacific $\left(0^{\circ}\right.$, $180^{\circ}$, EBENE cruise, Neveux et al., 2003). Hourly samples in the $30-$ $70 \mathrm{~m}$ layer permitted estimates of phytoplankton growth and grazing rates using the daily amplitude of the different parameters (IVF, pigment concentrations and beam attenuation). 
A

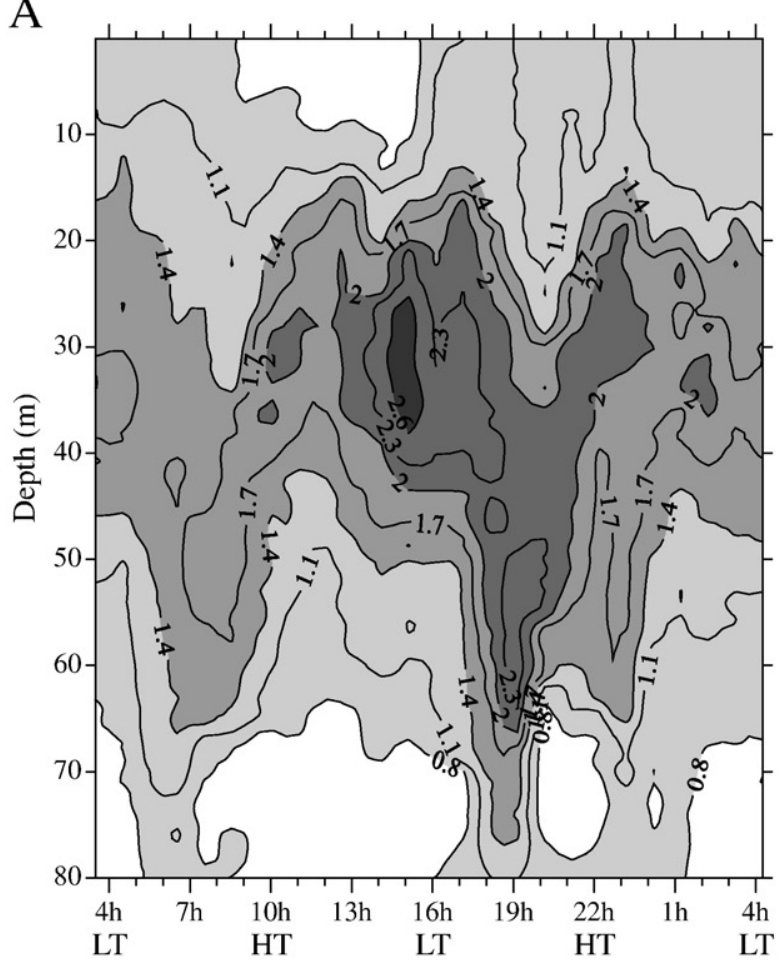

$\mathrm{C}$

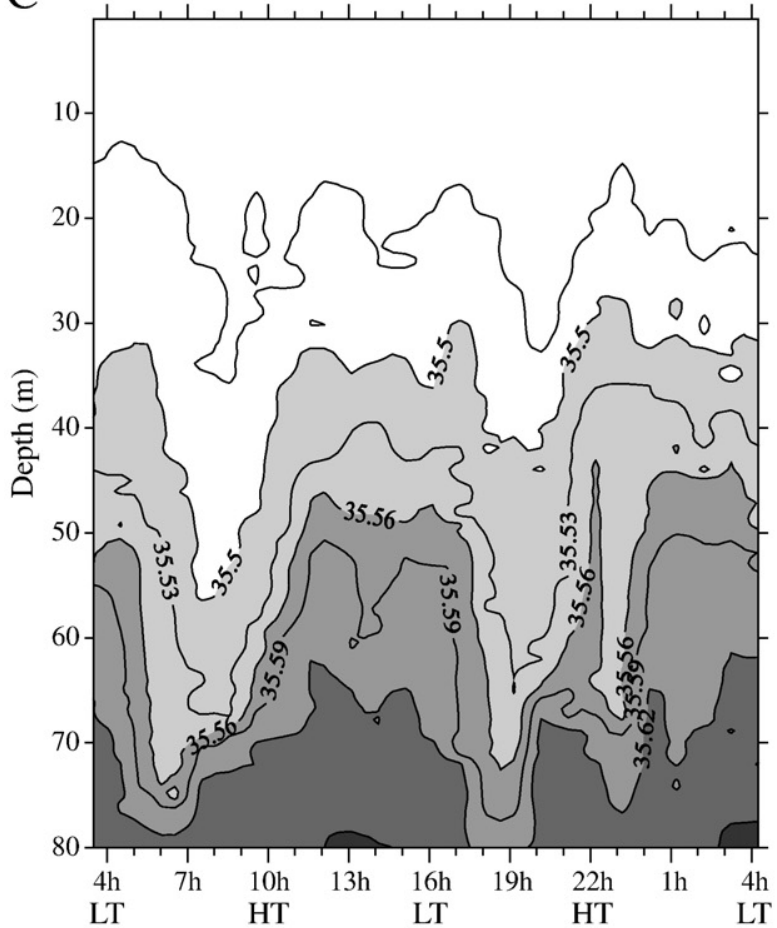

Day time (h)

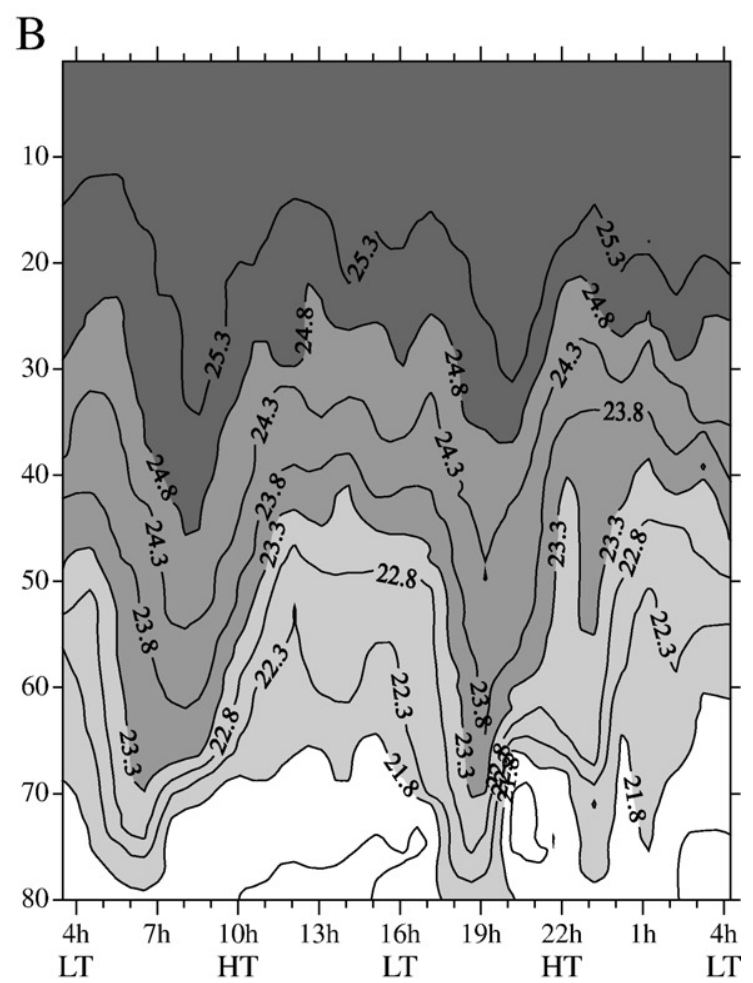

$\mathrm{D}$

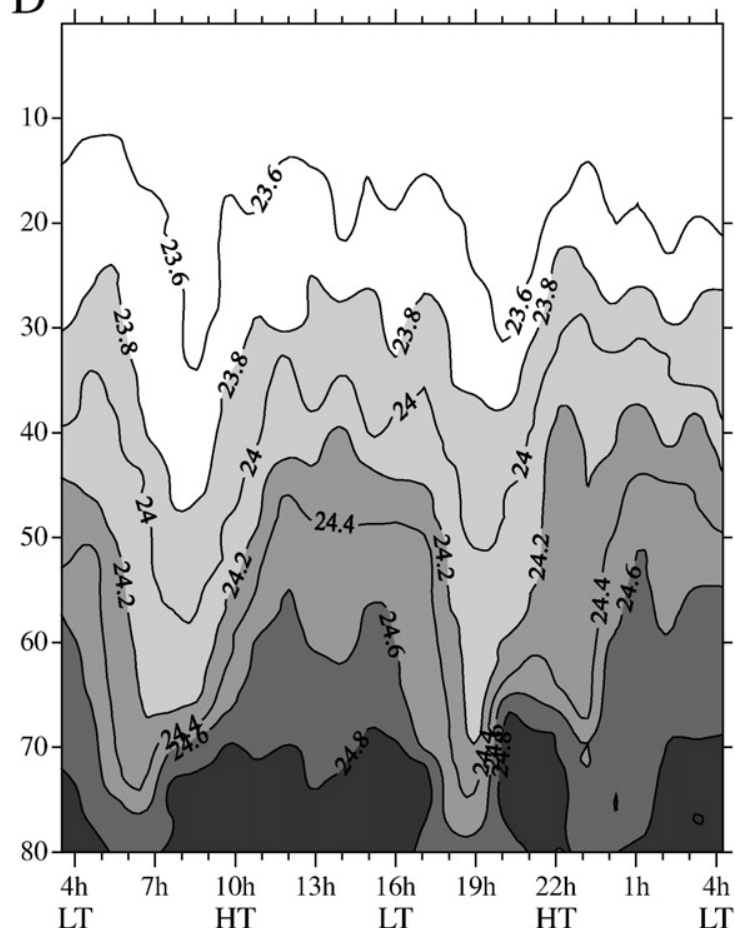

Day time (h)

Fig. 7. Time series at the station T29. A) In vivo chlorophyll $a$ fluorescence (r.u.), B) temperature $\left.\left({ }^{\circ} \mathrm{C}\right), \mathrm{C}\right)$ salinity, D) density $\left(\sigma_{\theta}\right)$; HT $=$ high tide; LT $=$ low tide.

In the present study, the situation was different since it concerned coastal waters subjected to both general and tidal currents and more variability in plankton standing stock and processes were expected. Nevertheless, the in situ IVF observations at the three fixed stations of the New Caledonian lagoon showed some features in common with those of the Equatorial Pacific. During the $25 \mathrm{~h}$ time series, the ship was moored to avoid drift from the initial position. The ADCP data, for the sampling at T4 or T29, suggested at first that water could pass and return to the position of sampling according to the oscillating tide. Unfortunately, the south-western current related to the maximum flood tide flow was clearly higher $\left(0.55 \mathrm{~m} \mathrm{~s}^{-1}\right)$ than the north-eastern current related to the maximum ebb tide flow $\left(0.4 \mathrm{~m} \mathrm{~s}^{-1}\right)$. Consequently, a global south-western displacement of waters occurred and return of waters at the initial location failed. This was confirmed by the circulation model recently developed for the southern part of the lagoon (Douillet and Le Gendre, 2008). However, it was possible to 


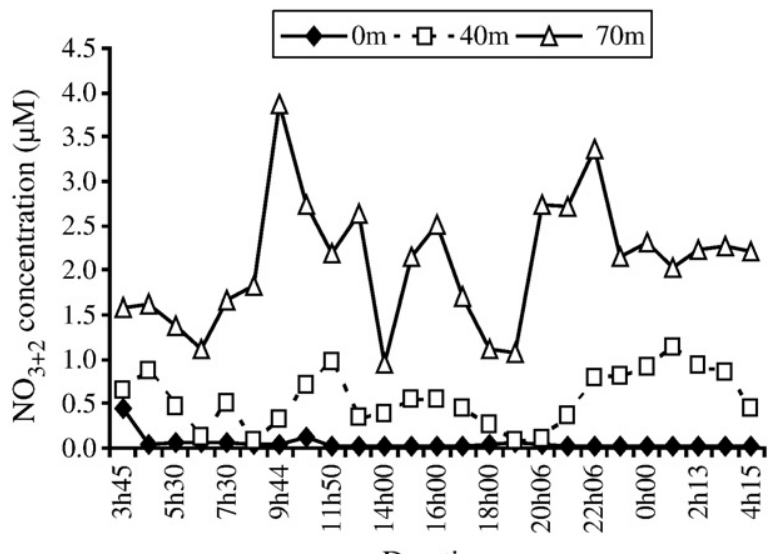

Day time

Fig. 8. Variations of the $\mathrm{NO}_{3+2}$ concentrations at the three depths sampled during the time series at the station T29.

A

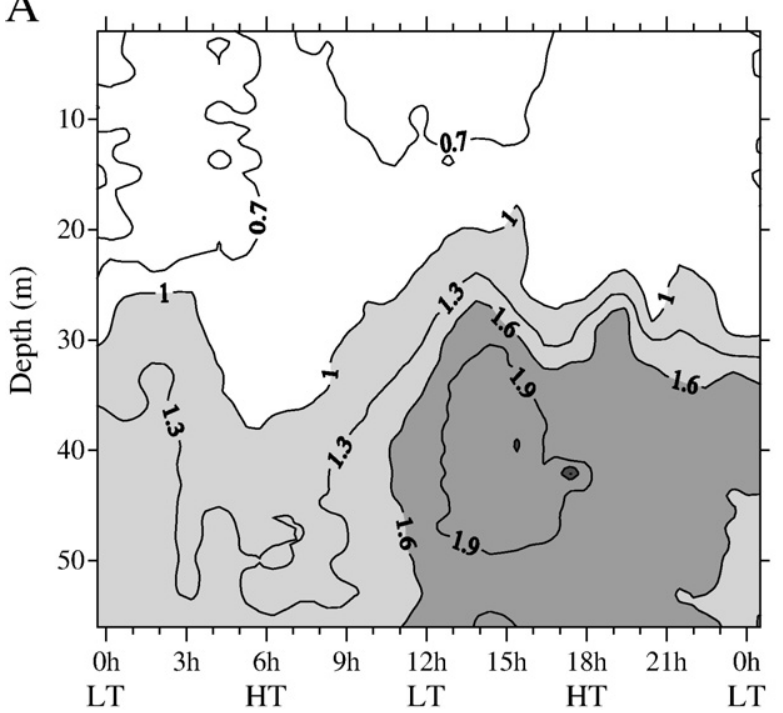

$\mathrm{C}$

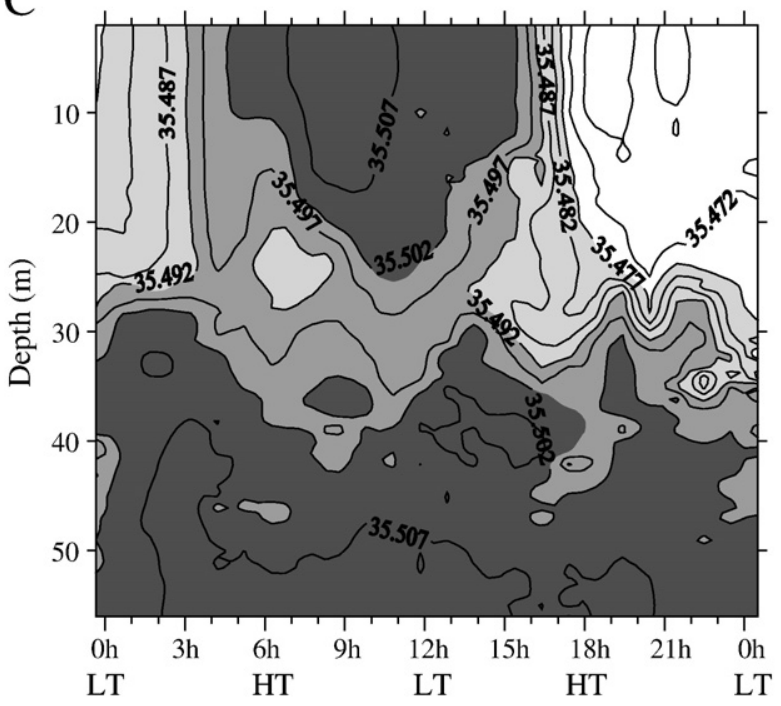

Day time (h) assume that the initial sampling geographical point belongs to a single water body sufficiently large so that this point remains within it for at least $25 \mathrm{~h}$. Considering the time series at T29, important vertical distribution changes were observed, but the Fmax remained in stable physical water conditions with a coefficient of variation of $1.3,0.04$ and $0.4 \%$ for temperature, salinity and $\sigma_{\theta}$, respectively. The Fmax variations were consistent enough to estimate the in situ phytoplankton gross growth rate and grazing rate. However, most field studies do not permit this type of analysis. To overcome the uncertainties related to water movement and community patchiness, a Lagrangian sampling strategy should be used for in situ phytoplankton growth rate estimates taking into account advection, diffusion, convergence and divergence fluxes (Hillmer and Imberger, 2007). Furthermore, the analysis assumes that local or remote hydrodynamic re-suspension of microphytobenthos related to wind and tide was negligible at the fixed stations (bottom depths $\geq 40 \mathrm{~m}$ ). However, this effect on diel IVF variations could be significant in very shallow waters $(<10 \mathrm{~m}$ ) if benthic diatoms migrate up and down into the sediment in function of the light-dark cycle (Clavier et al., 2005). Increases of turbidity, IVF and phaeopigments $a$ percentage [phaeopigments $a^{*} 100 /$ (phaeopigments $a+$ Tchl $a$ )] near the bottom are

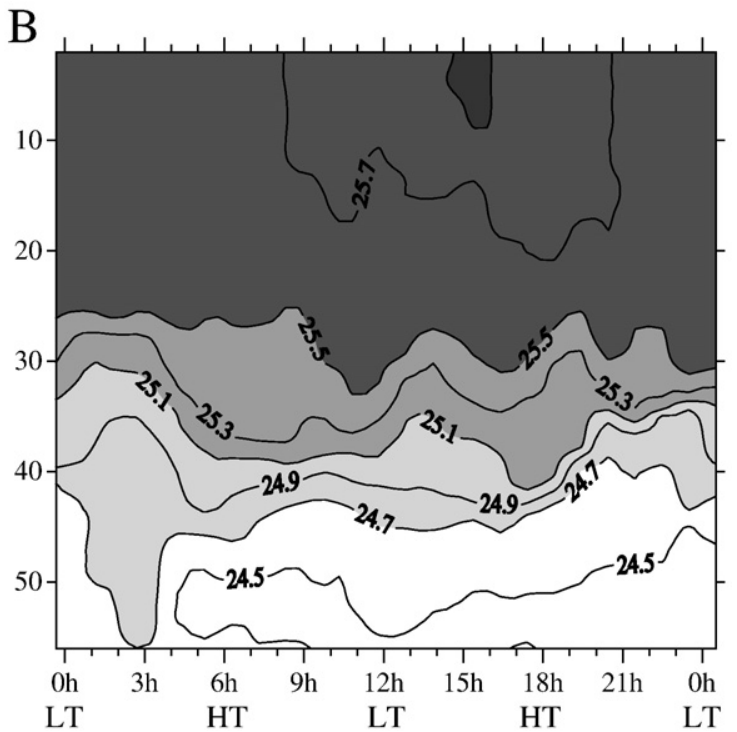

$\mathrm{D}$

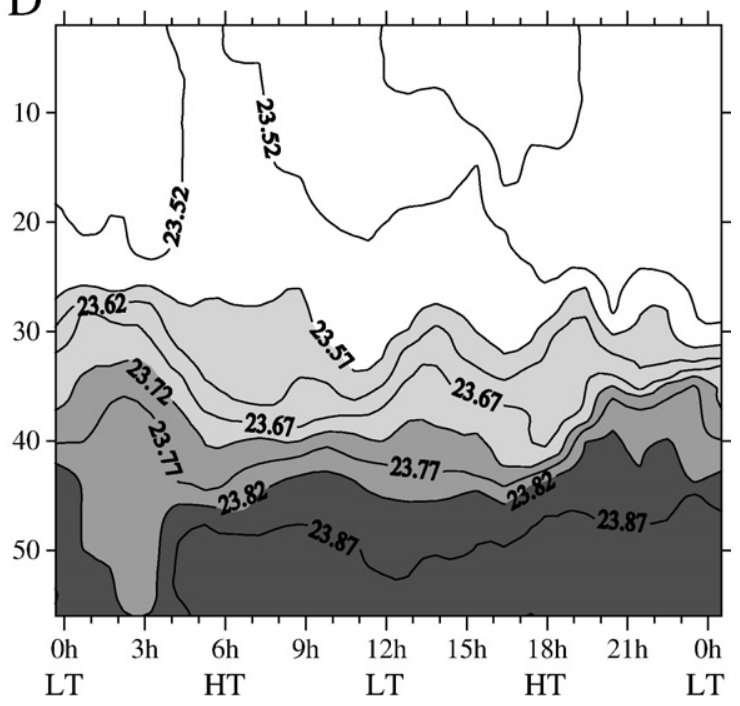

Day time (h)

Fig. 9. Time series at the station A11. A) In vivo chlorophyll $a$ fluorescence (r.u.), B) temperature $\left.\left({ }^{\circ} \mathrm{C}\right), \mathrm{C}\right)$ salinity, D) density $\left(\sigma_{\theta}\right)$; HT $=$ high tide; LT $=$ low tide. 
expected if significant local re-suspension occur. During the present study, there was no evidence of such increase, even at the shallowest station (T7: 22-23 m). Additionally, it was shown from hydrosedimentary numerical simulations (Douillet et al., 2001) that, in the lagoon of New Caledonia, re-suspension is negligible at the lagoon scale under tidal forcings alone, and generally results from the combined effects of tide and wind, at stations $<20 \mathrm{~m}$ in case of typical trade wind forcings.

\subsubsection{Biological problems}

In the surface layer, the fluorescence was strongly influenced by the non photochemical quenching (independent of Tchl $a$ and biomass) which occurs when the ambient illumination is high (Kiefer, 1973). This precludes the use of IVF to estimate phytoplankton growth and grazing during sunny days. In deeper layer $(>15 \mathrm{~m})$, fluorescence and Tchl $a$ were strongly correlated during each of the three time series $\left(R^{2}>0.8\right.$, $n=50$ ) and IVF (Fmax and Fint) changes showed a pattern justifying the use of the simple growth-grazing model. The I phase occurred between early morning (5:30-8:00 AM) and mid or late afternoon (3:00-7:00 $\mathrm{PM})$, coinciding with photonic energy input to the ecosystem by photosynthesis that could support phytoplankton growth. This phase can be compared with results obtained on different phytoplankton species cultured in $12 \mathrm{~h}$ artificial light-dark cycles with an increase of the Tchl $a$ cell $^{-1}$ concentration (and the global Tchl $a$ concentration) during the light period until about $8 \mathrm{~h}$ after the start of illumination (Jørgensen, 1966; Post et al., 1984; Jacquet et al., 2001). After the I phase, a decreasing $\mathrm{D}$ phase occurred until the following dawn and was mainly attributed to cell losses by grazing. By using a simple growth-grazing rate model, exponential regressions assessed the gross growth rate at about one division per day or more (Table 8 ). The model assumes that cell cycle matched the light-dark cycle (here 12 h $45-11$ h 15) with chlorophyll being synthesized during the light period until cell maturation. Thereafter, chlorophyll synthesis would occur only to maintain a nearly constant pigment pool in the global population until next dawn. During this period, chl $a$ cell $^{-1}$ is reduced according to the rate of cell division starting at the end of the afternoon or at night. The model considers that Tchl $a$ (or its IVF property) co-varies with carbon biomass and growth rate must equal cell number growth rate over $24 \mathrm{~h}$ (Binder and DuRand, 2002). As discussed previously (Neveux et al., 2003), different factors may affect the model outputs. The photoacclimation can lead to an imbalance between carbon fixation and chlorophyll synthesis, increasing cellular chl $a / C$ ratio during transition from high light to low light, and conversely from low light to high light (Falkowski, 1984; Post et al., 1984, 1985; Cullen and Lewis, 1988). This process depends on day to day light variations, on the light past history of cell, and is not present under dark conditions (Falkowski and LaRoche, 1991). "Full" photoacclimation takes one or several days in culture after exposition from a given light intensity to another (Post et al., 1984). In the ocean, cells experience continuously fluctuating light conditions, related to earth rotation, clouds, mixing, internal waves, and their photoacclimation kinetics are certainly more complex than in cultures. Furthermore, the model implies that changes in cellular chl $a$ after cell maturation (i.e. between the Tchl $a$ or IVF max and the following dawn) are only related to cell division. Eventual chlorophyll degradation would be compensated by new synthesis in the light or in the dark. In algae and cyanobacteria, two pathways of chlorophyll synthesis co-exist: one light-dependent and the other light-independent (Armstrong, 1998). It is still not known how much the light-independent pathway contributes to chl $a$ synthesis in natural populations (Rüdiger, 2006). An increase of the chl $a$ fluorescence per Prochlorococcus cell was reported in the equatorial Pacific during the second part of dark period (Vaulot and Marie, 1999; Neveux et al., 2003). Light-independent chl a synthesis could prepare the cell to drive photosynthesis with a maximum efficiency from first light. The timing of the I phase (start, duration and end) and the possible invalidation of the assumption that grazing rate is constant whatever the time of day, are two other possible sources of error. A priori, IVF would have to reach its minimum around sunrise when growth related chlorophyll synthesis began to exceed losses related to grazing, and would reach its maximum in mid afternoon when these losses exceeded synthesis. Consequently the duration of the I phase would be slightly longer than the lapse time between observed minimum and maximum. At T29, fixing the limit of the I phase for Fint was more difficult since the minimum and maximum occurred at 11:50 AM and 7:00 PM, respectively (Fig. 6), and were not observed around sunset and mid-afternoon as expected by the model. Nevertheless, considering the $11 \mathrm{~h} 50-19 \mathrm{~h}$ period as the I phase or a period beginning earlier; i.e. around $8 \mathrm{~h} 00$ did not modify significantly the specific growth rate estimates. Finally, a cell cycle strictly matching the $24 \mathrm{~h}$ light-dark cycle as that of Prochlorococcus in the equatorial Pacific suggests that the gross growth rate cannot exceed one division per day (Vaulot et al., 1995), but ultradian growth for this genus has been reported in the Arabian Sea (Shalapyonok et al., 1998).

In the present study, the estimated phytoplankton gross growth rates represented mean estimates on the global communities and could mask potentially large differences in growth rate of individual species. As in other tropical waters, oceanic and lagoon New Caledonian waters are generally dominated by picoplankton (Tenório et al., 2005; Jacquet et al., 2006; Neveux et al., 2009). Nevertheless, a relative increase in microplankton fraction in different bays (Jacquet et al., 2006) and estuaries (Tenório et al., 2005) are usually associated with nutrient input related to river run off or/and anthropogenic activities. A broad range of specific growth rates $(0.1-3)$ were assessed for the global communities of tropical and subtropical waters (see review of Furnas, 1990; Marañon, 2005). In tropical shelf waters of the Great Barrier Reef, incubation in diffusion chambers suggested $2-5$ cell doublings per day for diatoms and $<2$ for picoplankton (Furnas, 1991).

Phytoplankton growth models, developed from cultures, include up to ten variables: the main environmental factors, temperature, light and nutrients as well as three phytoplankton biomass indices (C, N and Tchl $a$, Geider et al., 1998). Therefore, It could seem biased to estimate phytoplankton growth from only one parameter, i.e. IVF a proxy of Tchl $a$. It has to be stated that gross growth rate estimates from IVF in this study fell in a relative narrow range (1-1.35 division $\mathrm{d}^{-1}$ ) although the nutrient status for the layer considered at each station was clearly different. At T29, $\mathrm{NO}_{3+2}$ concentration was relatively abundant with regard to $\mathrm{T} 4$ and $\mathrm{A} 11$. At A11, the $\mathrm{NH} 4$ concentration exceeded that of $\mathrm{NO}_{3}+2$, but not at $\mathrm{T} 4$.

\section{Conclusions}

The Echolag cruise results showed a significant nutrient enrichment of the THL region of New Caledonia during a trade wind event. This enrichment is related to a rise of the nitracline reinforced by tidegenerated internal waves and extends to the mid and bottom waters of the reef shelf and out to oceanic waters between the horns. The enrichment caused an increase in phytoplankton abundance at the surface which is more important between the horn reefs. The trade wind event during the cruise offered favourable conditions to estimate phytoplankton gross growth rate from in situ variations of in vivo chlorophyll $a$ fluorescence (IVF). IVF is the phytoplankton parameter which can be measured continuously by use of several fluorescence sensors (particularly, multiwavelength sensors) attached to mooring or drifting buoys (Marra, 1997). Associated with measurements of pressure, temperature, salinity, light, and transmissometry (assuming that diel variations in particle attenuation, $c_{\mathrm{p}}$, correspond to relative changes of phytoplankton carbon: Marra, 1997; Claustre et al., 1999; Neveux et al., 2003), chl $a$ fluorescence appears as a useful tool to develop a coupled physical biological model of phytoplankton dynamics during long time series. Furthermore the development of specific algorithm for retrieval of surface Tchl $a$ from satellite observation has to complete the information on phytoplankton dynamic in new Caledonian waters (Dupouy et al., in press). 


\section{Acknowledgements}

The authors thank the captain (H. Le Houarno) and crew of the R/V "Alis". They provide very efficient help at sea during sampling. We thank Mathieu Dolbecq and Catherine Rouchon (IRD-Nouméa) for technical assistance. We gratefully thank Jennifer Guarini (Observatoire Océanologique de Banyuls), Claire O'Donovan, Robert Le Borgne (IRD-Nouméa), and the anonymous referees for their helpful criticisms and English corrections. This work was supported by IRD, CNRS-INSU, the PNEC Nouvelle-Calédonie and the Programme prédictif IRD/GoroNIckel No. 1124 "Etude sur le comportement, la dispersion et les effets biologiques des effluents industriels dans le lagon de Nouvelle Calédonie".

\section{References}

Andréfouët, S., Cabioch, G., Flamand, B., Pelletier, B., 2009. A reappraisal of the diversity of geomorphological and genetic processes of New Caledonian coral reefs: a synthesis from optical remote sensing, coring and acoustic multibeam observations. Coral Reefs 28, 691-707.

Andrews, J.C., Gentien, P., 1982. Upwelling as a source of nutrients for the Great Barrier Reef ecosystems: a solution to Darwin's question? Mar. Ecol. Prog. Ser. 8, 257-269.

Armstrong, G.A., 1998. New trends in photobiology (invited review). Greening in the dark: light-independent chlorophyll biosynthesis from anoxygenic photosynthetic bacteria to gymnosperms. Journal of Photochemistry and Photobiology B: Biology 43, 87-100.

Binder, B.J., DuRand, M.D., 2002. Diel cycles in surface waters of the equatorial Pacific. Deep-Sea Res. II 49, 2601-2617.

Bonneton, P., Lefebvre, J.-P., Bretel, P., Ouillon, S., Douillet, P., 2007. Tidal modulation of wave-setup and wave-induced currents on the Aboré coral reef. New Caledonia. Journal of Coastal Research SI 50, 762-766.

Campbell, L., Vaulot, D., 1993. Photosynthetic picoplankton community structure in the Subtropical North Pacific Ocean near Hawaii (Station Aloha). Deep-Sea Research Part I 40, 2043-2060.

Claustre, H., Morel, A., Babin, M., Cailliau, C., Marie, D., Marty, J.-C., Tailliez, D., Vaulot, D., 1999. Variability in particle attenuation and chlorophyll fluorescence in the tropical Pacific: scales, patterns, and biogeochemical implications. Journal of Geophysical Research-Oceans 104, 3401-3422.

Clavier, J., Boucher, G., Chauvaud, L., Fichez, R., Chifflet, S., 2005. Benthic responses to ammonium pulses in a tropical lagoon: implications for coastal environmental processes. Journal of Experimental Marine Biology and Ecolog 316, 231-241.

Cullen, J.J., Lewis, M.R., 1988. The kinetics of algal photoadaptation in the context of vertical mixing. J. Plankton Res. 10, 1039-1063.

Dandonneau, Y., Neveux, J., 1998. Diel variations of in vivo fluorescence in the eastern equatorial Pacific: an unvarying pattern. Deep-Sea Res. II 44, 1869-1880.

Douillet, P., Le Gendre, R., 2008. Modélisation et simulation du transport des formes dissoutes et particulaires. Modèle Hydrodynamique, Notice technique-Validation. Convention IRD-Goro-Ni 1124. Rapport IRD-Nouméa 25/10/08. 54p.

Douillet, P., Ouillon, S., Cordier, E., 2001. A numerical model for fine suspended sediment transport in the south-west lagoon of New Caledonia. Coral Reefs 20, 361-372.

Dupouy, C., 1990. La chlorophylle de surface observée par le satellite NIMBUS-7 CZCS autour de la Nouvelle Calédonie et de ses dépendances. Une première analyse. Bulletin de l'Institut Océanographique de Monaco, $n^{\circ}$ Spécial $n^{\circ} 6$ "Halieutique, océanographie et télédétection : contribution française aux colloques francojaponais : thème télédétection", pp. 125-148.

Dupouy, C., Neveux, J., Ouillon, S., Frouin, R., Murakami, H., Hochard, S., Dirberg, G., in press. Satellite retrieval of chlorophyll concentration in the lagoon and open ocean waters of New Caledonia. Marine Pollution Bulletin, special issue on New Caledonia lagoons.

Falkowski, P.G., 1984. Kinetics of adaptation to irradiance in Dunaliella tertiolecta. Photosynthetica 18, 62-68.

Falkowski, P.G., LaRoche, J., 1991. Acclimation to spectral irradiance in algae. J. Phycol. 27, 8-14.

Fanning, K.A., Pilson, M.E.Q., 1973. On the spectrophotometric determination of dissolved silica in natural waters. Anal. Chem. 45, 136-140.

Fichez, R., Chifflet, S., Douillet, P., Gérard, P., Gutierrez, F., Jouon, A., Ouillon, S., Grenz, C, in press. Biogeochemical typology and temporal variability of lagoon waters in a coral reef ecosystem subject to terrigeneous and anthropogenic inputs (New Caledonia). Marine Pollution Bulletin, special issue on New Caledonia lagoons.

Furnas, M.J., 1990. In situ growth rates of marine phytoplankton: approaches to measurement, community and species growth rates. J. Plankton Res. 12, 1117-1151.

Furnas, M.J., 1991. Net in situ growth rates of phytoplankton in an oligotrophic, tropical shelf ecosystem. Limnol. Oceanogr. 36, 13-29.

Ganachaud, A., Vega, A., Rodier, M., Maes, C., Marchesiello, P., Eldin, G., Ridgway, K., Le Borgne, R., in press. Observed impact of upwelling on water properties and biological activity off the southwest coast of New Caledonia. Marine Pollution Bulletin, special issue on New Caledonia lagoons.
Geider, R.J., MacIntyre, M.L., Kana, T.M., 1998. A dynamic regulatory model of photoplanktonic acclimation to light, nutrients, and temperature. Limnol. Oceanogr. 43, 679-694.

Grasshoff, K., Eherhardt, M., Kremling, K., 1983. Methods of seawater Analysis, Second ed. Verlag Chemie, Weinheim, RFA. 419 p.

Hénin, C., Cresswell, G.R., 2005. Upwelling along Western Barrier Reef of New Caledonia. Marine and Freshwater Research 56, 1005-1010.

Hillmer, I., Imberger, J., 2007. Estimating in situ phytoplankton growth rates with a Lagrangian sampling strategy. Limnology and Oceanography: Methods 5, 495-509.

Holmes, M.R., Aminot, A., Kérouel, R., Hooker, B.A., Peterson, B.J., 1999. A simple and precise method for measuring ammonium in marine and freshwater ecosystems. Can. J. Fish. Aquat. Sci. 56, 1801-1808.

Jacquet, S., Partensky, F., Lennon, J.-F., Vaulot, D., 2001. Diel patterns of growth and division in marine picoplankton in culture. J. Phycol. 37, 357-369.

Jacquet, S., Delesalle, B., Torréton, J.-P., Blanchot, J., 2006. Response of phytoplankton communities to increased anthropogenic influences (southwestern lagoon, New Caledonia). Mar. Ecol. Prog. Ser. 320, 65-78.

Jørgensen, E.G., 1966. Photosynthetic activity during the life cycle of synchronous Skeletonema cells. Physiol. Plant. 19, 789-799.

Kattner, G., 1999. Storage of dissolved inorganic nutrients in seawater: poisoning with mercuric chloride. Mar. Chem. 67, 61-66.

Kiefer, D.A., 1973. Chlorophyll $a$ fluorescence in marine centric diatoms: responses of chloroplasts to light and nutrient stress. Mar. Biol. 23, 39-46.

Lantoine, F., Neveux, J., 1997. Spatial and seasonal variations in abundance and spectral characteristics of phycoerythrins in the Tropical Northeastern Atlantic Ocean. Deep-Sea Research Part I 44, 223-246.

Marañon, E., 2005. Phytoplankton growth rates in the Atlantic subtropical gyres. Limnol. Oceanogr. 50, 299-310.

Marra, J., 1997. Analysis of diel variability in chlorophyll fluorescence. J. Mar. Res. 55, 767-784.

Mullin, J.B., Riley, J.P., 1955. The spectrophotometric determination of silicate-silicon in natural waters with special reference to sea water. Anal. Chim. Acta 12, 162-170.

Neveux, J., Lantoine, F., 1993. Spectrofluorometric assay of chlorophylls and phaeopigments using the least squares approximation technique. Deep-Sea Research Part I 40, 1747-1765.

Neveux, J., Dupouy, C., Blanchot, J., Le Bouteiller, A., Landry, M.R., Brown, S.L., 2003. Diel dynamics of chlorophylls in high-nutrient, low-chlorophyll waters of the Equatorial Pacific $\left(180^{\circ}\right)$ : interactions of growth, grazing, physiological responses, and mixing. Journal of Geophysical Research-Oceans 108 (C12), 8140 doi:10.1029/ 2000JC000747.

Neveux, J., Tenório, M.M.B., Dupouy, C., Villareal, T.A., 2006. Spectral diversity of phycoerythrins and diazotroph abundance in tropical waters. Limnol. Oceanogr. 51, 1689-1698.

Neveux, J., Tenório, M.M.B., Jacquet, S., Torréton, J.-P., Douillet, P., Ouillon, S., Dupouy, C., 2009. Chlorophylls and phycoerythrins as markers of environmental forcings including cyclone Erica effect (March 2003) on phytoplankton in the southwest lagoon of New Caledonia and oceanic adjacent area Article ID 232513, 19 pages International Journal of Oceanography vol. doi:10.1155/2009/232513.

Ouillon, S., Douillet, P., Lefebvre, J.-P., Le Gendre, R., Jouon, A., Bonneton, P., Fernandez, J.-M., Chevillon, C., Magand, O., Lefèvre, J., Le Hir, P., Laganier, R., Dumas, F. Marchesiello, P., Bel Madani, A., Andrefouët, S., Panché, J.Y., Fichez, R., in press. Circulation and suspended sediment transport in a coral reef lagoon: the southwest lagoon of New Caledonia. Marine Pollution Bulletin, special issue on New Caledonia lagoons.

Post, A.F., Dubinsky, Z., Wyman, K., Falkowski, P.G., 1984. Kinetics of light-intensity adaptation in a marine planktonic diatom. Mar. Biol. 83, 231-238.

Post, A.F., Dubinsky, Z., Wyman, K., Falkowski, P.G., 1985. Physiological responses of a marine planktonic diatom to transitions in growth irradiance. Mar. Ecol. Prog. Ser. $25,141-149$.

Raimbault, P., Slawyk, G., Coste, B., Fry, J., 1990. Feasibility of using an automated colorimetric procedure for the determination of seawater nitrate in the 0 to $100 \mathrm{nM}$ range: examples from field and culture. Mar. Biol. 104, 347-351.

Rowan, K.S., 1989. Photosynthetic Pigments of Algae. Cambridge University Press, New York.

Rüdiger, W., 2006. Biosynthesis of chlorophylls a and b: the last steps. In: Grimm, B., Porra, R.J., Rüdiger, W., Scheer, H. (Eds.), Chlorophyll and Bacteriochlorophyll: Biochemistry, Biophysics, Function and Applications. Springer, the Netherlands, pp. 189-200.

Shalapyonok, A., Olson, R.J., Shalapyonok, L., 1998. Ultradian growth in Prochlorococcus spp. Appl. Environ. Microbiol. 64, 1066-1069.

Tenório, M.M.B., Le Borgne, R., Rodier, M., Neveux, J., 2005. The impact of terrigeneous inputs on the Bay of Ouinné (New Caledonia) phytoplankton communities: a spectrofluorometric and microscopic approach. Estuar. Coast. Shelf Sci. 64, 531-545.

Thomson, R.E., Wolanski, E.J., 1984. Tidal period upwelling within Raine island entrance great barrier reef. J. Mar. Res. 42, 787-808.

Vaulot, D., Marie, D., 1999. Diel variability of photosynthetic picoplankton in the equatorial Pacific. Journal of Geophysical Research-Oceans 104, 3297-3310.

Vaulot, D., Marie, D., Olson, R.J., Chisholm, S.W., 1995. Growth of Prochlorococcus, a photosynthetic prokaryote, in the equatorial Pacific Ocean. Science 268, 1480-1482.

Wood, E.D., Armstrong, F.A.J., Richards, F.A., 1967. Determination of nitrate in sea-water by cadmium-copper reduction to nitrite. J. Mar. Biol. Assoc. UK 47, 23-31.

Wyman, M., 1992. An in vivo method for the estimation of phycoerythrin concentrations in marine Cyanobacteria (Synechococcus spp.). Limnol. Oceanogr. 37, 1300-1306. 